\title{
ALUSIONES A LA SEXUALIDAD EN ALGUNAS TRAGEDIAS CONSERVADAS DE EURÍPIDES
}

\author{
JUAN ANTONIO LÓPEZ FÉREZ \\ Universidad Nacional de Educación a Distancia (Espanha)
}

RESUMO: Este artigo pretende verificar alusões à sexualidade, explícitas ou veladas, em nove tragédias de Eruípides.

PALAVRAS-CHAVE: Eurípides; tragédia; sexualidade.

La comedia griega antigua, es bien sabido, abunda en expresiones sexuales de toda clase, pues la libertad de palabra, incluida la referencia específica al acto sexual y a las partes masculinas y femeninas que intervienen en él, era una de las constantes del género literario, en íntima conexión con los rituales demetriacos y dionisiacos. Algo parecido, aunque en grado menor, sucede en el llamado drama satírico, o cuarta pieza que acompañaba a cada trilogía trágica.

Por otro lado, según leemos en numerosos estudios generales dedicados a la tragedia, este género evita, por lo general, toda mención directa de la sexualidad. Efectivamente, leyendo las tragedias conservadas de los tres trágicos se observa, a primera vista, que rara vez aparecen referencias evidentes al acto sexual, los órganos genitales y las diversas variantes de la sexualidad divina o humana.

Pues bien, mi propósito ha sido hacer una lectura reposada y detallada de las piezas euripideas, por si pudiera afirmarse que, aquí y allá, encontramos alguna indicación, más o menos velada, referente a la sexualidad de seres divinos o humanos. El lector habrá de juzgar los datos que les doy en este trabajo provisional, preparatorio. Personalmente estoy convencido de que nuestro trágico, innovador en tantos sentidos, utiliza una libertad dada por la tradición literaria, aunque muy mal conocida por nosotros, y, en virtud de la cual, si bien se evitan las palabras directas, o los gestos inequívocos de índole sexual, sí se emplean términos, expresiones y quizá motivos escénicos que apuntan al campo de la sexualidad. Todo ello nos permite pensar en un origen común, o muy cercano, de tragedia y comedia. Ambas recogen ritos demetriacos, ligados al ciclo de las cosechas, a la nueva vida, la muerte y la resurrección, bien conocidos desde Arquíloco; son elementos esen- 
ciales que, en buena medida, se hallan también en el dionisismo, religión a la que están ligadas las dos desde sus inicios.

En esta redacción provisional he creído conveniente ofrecer no sólo las alusiones explícitas o veladas a la sexualidad, sino también otras referencias indirectamente relacionadas con la esfera sexual, o que la bordean tangencialmente, tales como ciertas expresiones relativas al matrimonio o la unión heterosexual (no faltan, por lo demás, menciones de homosexualidad en nuestro poeta).

Prescindo de los testimonios del Ciclope euripideo, pues, como drama satírico, el único completo que nos ha llegado, entra de lleno en lo que he dicho al comienzo. Sigo un orden cronológico en las tragedias de que me ocupo. Prescindo de las restantes por no extenderme en demasía.

\section{Alcestis}

1. Cuando la protagonista se está despidiendo del lecho conyugal se expresa de este modo:

“iOh lecho, donde la virginal doncellez perdí yo

por obra de este varón por el que muero!

iPásalo bien! No te odio; me aniquilaste a mí, casi. Negándome a traicionaros a ti y a mi esposo, muero. A ti otra mujer te poseerá;

no sería prudente en mayor medida, mas quizá feliz" ${ }^{1}$

Alcestis está tan afectada por su muerte inmediata que, refugiada en la alcoba matrimonial, le dirige la palabra al lecho, claro apóstrofe. Hay una serie de elementos de alto significado para comprender cómo era la vida sexual de una mujer digna y recatada como ella. Ha sido en ese lecho (léktron) donde perdió la virginidad; es decir, la protagonista se había mantenido doncella hasta que pasó a vivir en el palacio de Admeto, su esposo. El adjetivo parthéneios, "propio de vir-

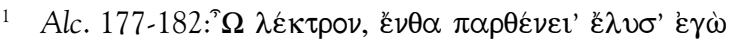

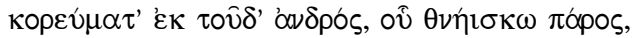

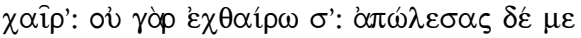

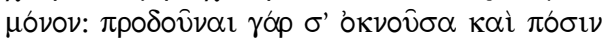

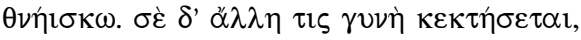

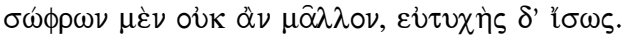


gen”, de la familia de parthénos, merece un estudio aparte. Atención oportuna habría que dedicarle asimismo al sustantivo koreúmata, en plural².

El lecho conyugal, pues, es tan importante que merece el monólogo de una persona que iba a morir poco después. Es importante señalar que hay una cierta contradicción entre la certeza con que Alcestis afirma que otra mujer poseerá el lecho, es decir, tras haber contraído matrimonio con Admeto, y lo que veremos después cuando la protagonista le pida a su esposo que no se case con nadie. Nótese también, dentro de la personificación del lecho, que, en cierto modo, se le acusa de ser la causa de la destrucción de Alcestis (apôlesas d'emè / mónon), cuando, en realidad, ha sido Admeto el responsable de la inminente muerte de su esposa. Otra nota de indudable interés es la referencia a que no ha querido traicionar ni al lecho ni al esposo, donde podría entenderse que no ha querido seguir viviendo, pues, en tal caso, una vez muerto Admeto, podría haberse casado con otro y seguir habitando en el palacio real. Se entiende mejor lo de traicionar a Admeto, porque nadie ha querido morir por él salvo ella, con lo que ha demostrado su entrega máxima, la vida.

Relevante es, asimismo, el verbo lýô, "desatar, soltar, perder", construido aquí con un genitivo de causa (mediante la preposición ek), referido a una persona: "por la acción de, por obra de".

2. Alcestis, por lo demás, menciona "el lecho virginal de su patria Yolco"3. Es decir, la protagonista afirma que era virgen cuando vivía en la mansión paterna, a saber, en Yolco.

3. En su conversación con Admeto, la protagonista le pide a su esposo que no se case en segundas nupcias con una mujer que sería madrastra para sus hijos y que les pondría la mano encima (es decir, los castigara físicamente). Él le responde que ninguna otra mujer tesalia se llamará su esposa; durante toda su vida suprimirá los festines, reuniones de invitados, coronas y cantos; no tocará la lira ni cantará al

2 Es un derivado de kóros (koûros en jónico-ático), femenino kórê. De ahí procede también el verbo koreúomai, "llevar la vida propia de una joven" (Cf. Alc. 313), que ya en Ferecides significa "perder la virginidad”. Entre los cómicos, por lo demás, es usual el derivado ekkorízô, "desflorar". En autores tardíos, diakoreúomai significa "ser desflorada": así en Artemidoro, Sorano, Luciano, etc. Particularmente notable es el participio de perfecto medio-pasivo: diakekoreuménê, "desflorada": cf. Sorano, 1.7.2. Eurípides es el primero y el único, al menos hasta fines del $\mathrm{V}$ a. C., en utilizar koreúmata.

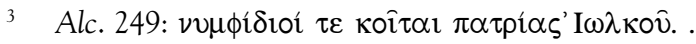


son de la flauta libia; y, además, encargará a los escultores un cuerpo como el de Alcestis y "quedará tendido en el lecho" ${ }^{4}$

"junto a él me echaré y poniéndole en torno las manos, llamándolo por tu nombre, a mi esposa querida en los brazos creeré tener, aun no teniéndola.

Frío deleite, pienso, mas, con todo, la pena de mi alma aliviaría (...) ${ }^{m}$

Podría verse aquí un indicio de lo que algunos entienden como agalmatofilia, desviación sexual caracterizada por una pasión erótica hacia las estatuas. Realmente, Admeto afirma que sentiría un deleite "frío", por estar abrazado a la estatua, pequeña compensación, en efecto, frente al placer verdadero experimentado al acariciar a la esposa de carne y hueso.

Admeto, tras haber dado dar sepultura a su esposa, vuelve a su mansión, y afirma:

"Envidio a los muertos; de ellos estoy enamorado;

aquellas mansiones deseo habitar(...)"6.

Es sin duda sorprendente decir que se está enamorado de un muerto, lo que merecería un comentario especial que ahora no puedo acometer, pero en donde podría pensarse en una desviación del erotismo.

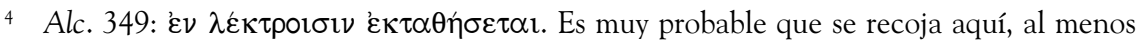
parcialmente, el mito de Protesilao, de cuya figura su esposa Laodamía hizo una estatua junto a la que dormía en su lecho conyugal. El mito es de origen tesalio, como el de Alcestis. La influencia de la leyenda de Protesilao podría verse reflejada asimismo en las palabras de Admeto cuando afirma que su esposa volvería a él en sueños y lo consolaría. Precisamente, a Protesilao le dedicó Eurípides una tragedia de la que nos han llegado escasos fragmentos.

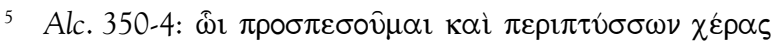

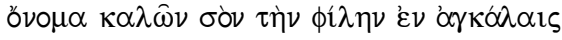

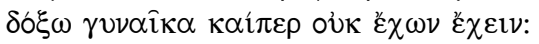

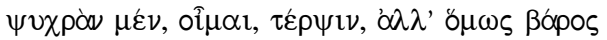

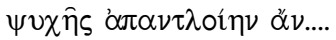

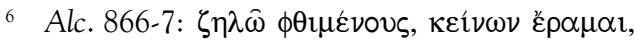

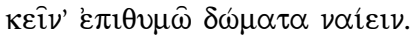


4. Cuando Heracles quiere dejarle a Admeto una mujer (Alcestis, en realidad) que ha ganado en un premio, éste se resiste y le pide que se la entregue a cualquier otro tesalio, pues se trataba de una mujer joven. La secuencia tiene evidentes perfiles melodramáticos.

"iAcaso habitará mi morada entre varones?

Y icómo intacta ${ }^{7}$, desenvolviéndose entre jóvenes, estará? Al joven, Heracles, no es fácil contenerlo. Yo tengo previsión por ti.

¿O admitiéndola en la alcoba de la muerta he de cuidarla?

¿Y cómo poner a ésta en el lecho de aquélla?

Doble censura temo: de las gentes del pueblo, no vaya a reprocharme alguien de traicionar a mi bienhechora y caer en el lecho ${ }^{8}$ de otra joven;

y, además, de la muerta: merece que la honre" ${ }^{\prime}$.

7 Destaca el adjetivo akraiphnês, que sólo aparece dos veces en Eurípides; aquí y en Hec.537, donde califica la sangre pura de una doncella. Muy poco usado en el V a. C, siglo en que encontramos los primeros ejemplos. La etimología es dudosa. Sin duda importante es la reflexión sobre la dificultad de que una mujer joven se mantenga pura (doncella, podríamos añadir nosotros) si tiene que desenvolverse entre hombres jóvenes (néois). El momento culminante de esta reflexión es la hipótesis de poner a esa mujer joven en la propia alcoba matrimonial y allí cuidarla (alimentarla, dice el texto): la situación, pues, no carece de aspectos cómicos.

8 Otro término relevante es el sustantivo démnion, "colchón", "cama": palabra homérica que alude a lo que se extiende, pero es distinto de la cubierta y otros accesorios que pueden adornar el lecho. Admeto habla abiertamente de echarse en el colchón con esa joven. Ese sería el motivo de la censura tanto por parte de las gentes del pueblo como de la muerta. La alusión, creo, a la unión sexual se vislumbra.

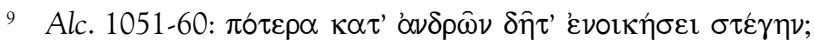

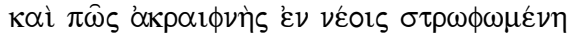

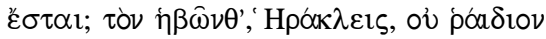

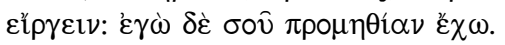

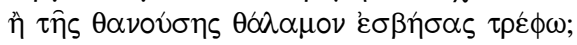

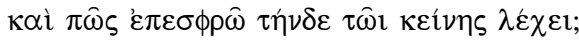

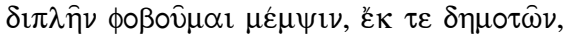

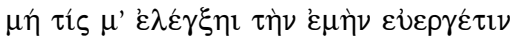

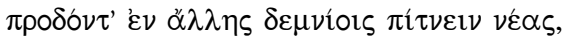

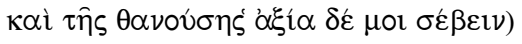


Heracles, tras replicarle a su amigo afirmando que "amar (philêsai) a quien ha muerto acarrea lágrimas" ${ }^{10}$, sigue conversando con él en un diálogo esticomítico:

Heracles. - "Una mujer te calmará y los deseos hacia tu nueva esposa.

Admeto. - iCállate! ¿Qué has dicho? No lo hubiera creído.

Heracles. - iY qué? ¿No te casarás sino que tendrás viudo el lecho?

Admeto. - No hay mujer que vaya a acostarse junto a éste ${ }^{11}{ }^{12}$.

\section{Medea}

1. En el prólogo, la nodriza expone la situación de la heroína, a quien, abandonada por Jasón, todo le resulta odioso y está enferma de lo que más quiere (noseî tà phíltata $)^{13}$ :

"Tras traicionar a sus propios hijos y a mi señora, con esposa real se acuesta Jasón, habiéndose casado con la hija de Creonte, que gobierna el país"14.

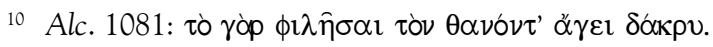

11 Señalándose a sí mismo, quizá, con el dedo.

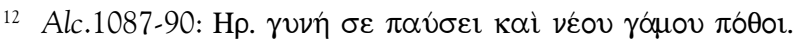

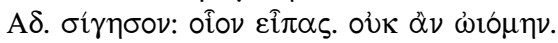

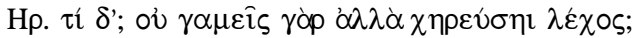

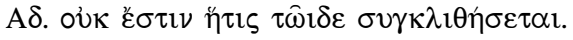

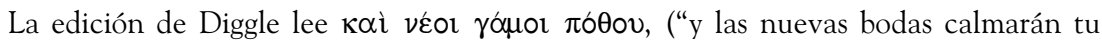
deseo") corrección propuesta también por A. M. Dale. Es decir, el sujeto de paúsei serían tanto gynê como gámoi. Sintácticamente es posible. Ahora bien, si es cierto que el verbo paúô se suele construir con genitivo no está descartada la coherencia léxica en la lectura ofrecida por los manuscritos. De atenernos a ésta, gámou se referiría, no al matrimonio, sino a la unida en matrimonio, es decir, la casada.

Dejando para otro momento el comentario de "tener viudo el lecho", la que resulta evidente es la forma verbal synklithêsetai, "acostarse junto con", es decir, otra referencia conspicua a la unión sexual, si bien por via eufemística.

13 Med.16. En el amor como enfermedad habrá que insistir más adelante.

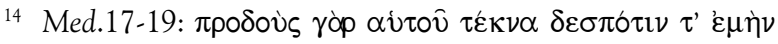

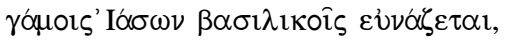

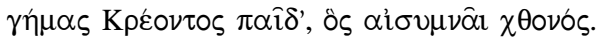


Se acumulan en dos versos tres términos correspondientes al campo de la sexualidad: gámois, eunázetai, gēmas. Efectivamente, desde la Ilíada, eunasthênai se emplea para expresar la unión sexual ${ }^{15}$.

2. Por su parte, el Coro se expresa de este modo:

"¿Qué deseo tienes del inaccesible

lecho, oh infeliz?" ${ }^{16}$.

3.Medea, a su vez, en un discurso dirigido a las mujeres corintias ${ }^{17}$, se extiende en las diferencias existentes dentro del matrimonio entre hombre y mujer ${ }^{18}$ : ésta debe comprar un marido con excesivo gasto de dinero y conseguir un dueño del propio cuerpo ${ }^{19}$; las separaciones (apallagaí) ${ }^{20}$ no reportan buena fama a las mujeres; hay que saber tratar bien al compañero de lecho (xyneunétēi) ${ }^{21}$; un varón, cuando se cansa de convivir con los de su hogar, se marcha fuera, a casa de un amigo o de uno de su edad ${ }^{22}$, y, en cambio, la mujer ha de poner los ojos en un hombre solo.

15 Il.3.448.

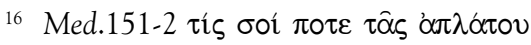

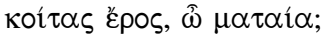

17 El Coro, ciertamente; no obstante, esas reflexiones están pensadas para los espectadores (incluyendo las mujeres que hubiera presentes durante la representación) en general.

18 Med.230-247. Son observaciones de gran importancia, pues suponen una visión panorámica de la sociedad ateniense correspondiente a los años en que la obra fue representada.

19 Censura de lo elevado de la dote y de la sumisión de la esposa al marido.

20 El término está usado con propiedad. Efectivamente, aunque la esposa puede pedir la separación en caso de malos tratos o de infidelidad, raramente acudía a denunciar esos extremos.

21 Eurípides, como en tantos otras ocasiones, se muestra experto en el empleo de términos que hacen referencia al lecho o lo que en tal lugar sucede. Así ocurre con xyneunétês, "compañero de lecho", que no aparece hasta él; lo emplea en cinco ocasiones. También es el primero en utilizar el femenino correspondiente (xyneunétis). Si eunê es un sustantivo

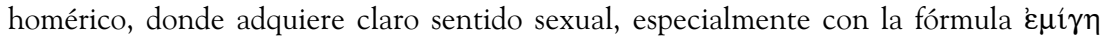

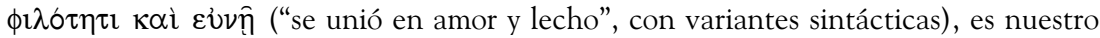
trágico el que más lo utiliza en sus obras, destacando con mucho sobre los otros dos tragediógrafos.

22 Hay que suponer que con la intención de irse con alguna mujer en compañía de su amigo. Se entiende así mejor lo que viene a continuación, de que las mujeres deben conformarse con mirar a un solo hombre. 
La exposición viene cerrada por unas frases que nos dan pistas abundantes de por dónde va a transcurrir la tragedia. La protagonista quiere que Jasón pague su pena (díkên) por los males que ha cometido contra ella, pero también desea que ese castigo sea para quien le ha dado a su hija en matrimonio y para la recién casada. En esta secuencia encontramos una reflexión de aparente validez universal: una mujer es miedosa, generalmente, y cobarde, pero cuando es injuriada en lo referente a su lecho (es eunēn èdikèménē) no hay otra mente más sanguinaria.

4. En el agón retórico sostenido frente a Jasón, la protagonista afirma:

“(...)Si estuvieras sin hijos, perdonable te sería enamorarte de ese lecho"23.

5. Jasón tiene también sus argumentos, bastante cínicos, por cierto:

"No, con lo que te irritas, porque odiara tu lecho, ni por el deseo de nueva esposa perturbado" ${ }^{24}$.

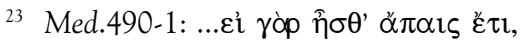

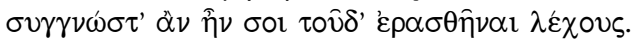

El sustantivo léchos, homérico, sólo en la Odisea presenta una cierta diferencia semántica con respecto a eunê. La distribución del empleo del primero en los tres trágicos es la siguiente: Esquilo (6), Sófocles (15, donde ya encontramos el valor de "esposa", "concubina"), Eurípides (132). Sólo el número de apariciones ya nos permite imaginar la importancia que tal sustantivo tiene para nuestro trágico. Hay obras en que se convierte en una verdadera idea central, repetitiva. Así, destacan, por número de ejemplos, Med. (19), Hel. (18), Andr. (15), Hipp. (8), etc.

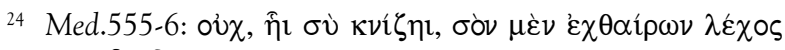

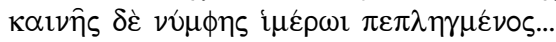

Estos dos versos merecen un comentario algo extenso. Desde Homero nýmphê quiere decir joven en edad de casarse o recién casada. También alude a las Ninfas, en sus distintas modalidades. Eurípides muestra especial predilección por derivados de esta palabra, como viene demostrado por los numerosos términos innovadores que aporta en sus obras: dýsnymphos; kakónymphos; nympheutêria, "matrimonio"; nympheutês, "el amigo que acompaña al novio"; nymphídios; pseudonýmpheutos. De 128 ejemplos en aparece la raíz nymph- en nuestro trágico, según los datos que pueden conseguirse mediante el TLG, en Medea tenemos 21. Si nos fijamos sólo en nýmphê, la encontramos en diez secuencias: $163,556,785,805,888,957,978,1003,1066,1179$. Siempre se refiere a la recién casada con Jasón, la joven princesa hija de Creonte. Por su parte, hímeros, bien conocido desde Homero, término de etimología dudosa, adquiere un indudable contenido sexual desde los poemas homéricos, como la pasión ardiente, el 
Las mujeres, añade, si acontece alguna adversidad en lo pertinente a su lecho (Med.571: xymphorá tis es léchos), lo más conveniente y lo más hermoso lo toman por lo más hostil.

6. Medea, en los versos que cierran este diálogo imposible, habla de este modo:

"iMárchate! iDe deseo hacia la muchacha recién casada eres presa al demorarte lejos de palacio!.

iGoza tu boda! Quizá - y se dirá con ayuda de un dios celebres un casamiento tal que te arrepientas de él”25.

7. El Coro, en el segundo estásimo, rechaza los amores excesivos y venera a Cipris mesurada; le pide a la diosa que no dispare su dardo ungido de deseo (himérôi); asimismo, que Cipris no le trastorne el ánimo con otro lecho (hetérois epì léktrois), sino que, venerando las uniones pacíficas (aptolémous d'eunàs sebízousa), elija sabiamente el matrimonio con mujeres (léchē gynaikôn).

8. Se presenta en escena Egeo, rey de Atenas, y habla con la protagonista: viene de Delfos donde ha consultado el oráculo, pues no ha podido tener hijos. He

deseo arrebatado que lleva a los amantes, o matrimonio constituido, a marcharse al lecho para consumar el acto amoroso. Il.3.446 nos presenta a Paris cuando le pide a Helena irse juntos a la cama: "estoy enamorado de ti y dulce deseo me apresa"; Il.14.198 nos habla de la reina celestial, Hera, pidiéndole a Afrodita el amor y el deseo "con que a todos dominas"; la diosa del deseo erótico la complace, sacándolos de una cinta que llevaba en el pecho, donde se encontraban esos dos y, además, la seducción; en Il.14.328 es Zeus, el padre de hombres y dioses, el que se declara amorosamente a su esposa y hermana Hera, afirmando que nunca la había deseado tanto, de tal modo que rápidamente se metieron juntos en el lecho, donde, con poquísimo tacto, el gran dios le habló de varias amantes con las que se había unido anteriormente. Podría entenderse hímeros, en este caso, no sólo como el deseo súbito de unirse sexualmente, sino, además, la gana incoercible de hablar de experiencias sexuales anteriores. Aparte del contenido fuertemente sexual propio de hímeros, ya Esquilo había usado la fórmula himérôi peplêgménos (A.544, 1203: en este último ejemplo se trata de Apolo, herido de deseo hacia Casandra; entiéndase, desde luego, deseo sexual), y, además, en fin de verso, como en el caso euripideo que estamos examinando.

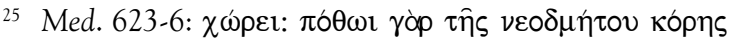

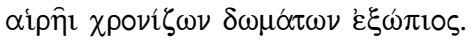

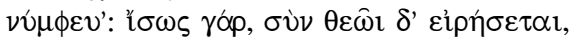

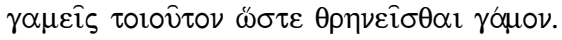


aquí sus palabras: "Inquiriendo cómo se me produciría simiente de hijos" ${ }^{26}$. La respuesta oracular no es fácil de interpretar, pues decía lo siguiente: "Que no suelte el pie que sobresale del odre"27. Una vez que Medea dijera que Jasón se había casado, he aquí un fragmento del diálogo subsiguiente:

"Egeo. - $i$ Tras enamorarse o por odio a tu lecho?

Medea. - Por un gran amor. No es fiel a los suyos" ${ }^{28}$.

9. Cuando Medea, de modo sorprendente para su carácter firme y férreo, le pide perdón a Jasón, aparenta ceder y desear llegar a un acuerdo con él, pues quiere ganar tiempo y poder enviar a sus hijos con los regalos letales, su antiguo esposo habla de este modo:

"Es natural que el sexo femenino manifieste irritación contra el esposo si contrae otro matrimonio ilegal"29.

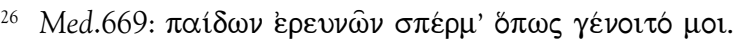

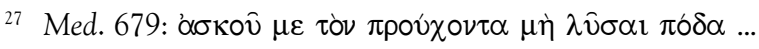

El sustantivo askós, "odre de cuero", es bien conocido desde Homero (Cf. Od. 5.265; 9.196). Por su forma y aspecto fue utilizado rápidamente con un sentido erótico. Así leemos en Arquíloco (Fr.119.1): "Y caer sobre el odre preparado, y vientre con vientre / juntar, y muslos con muslos". Entre los trágicos no aparece en los dos primeros; Eurípides, en cambio, ofrece siete secuencias (cinco en Ciclope, ésta y otra en El.511). Por lo demás, Aristófanes no lo utiliza en sentido sexual.

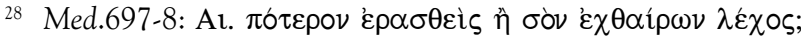

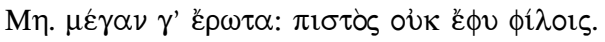

Se desprende de las palabras de Egeo que Jasón podía haberse casado bien por haberse enamorado de otra, bien por odio a Medea. Entiéndase la frase mégan g'érôta, como acusativo interno de erastheís. El reproche de Medea apunta al nuevo matrimonio de Jasón, no a que tuviera amores con otra, pues en la sociedad ateniense del siglo $\mathrm{V}$ las amantes de un varón casado estaban protegidas por la ley (Cf. Lisias, 1.31).

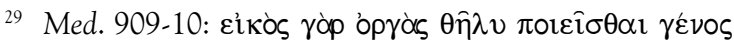

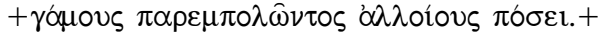

Es un texto bastante difícil, tanto que varios editores lo ofrecen como sospechoso. Tómese nuestra traducción, nada literaria, como provisional. Lo que parece que está sano en la secuencia es la construcción del genitivo parempolôntos, "adquirir algo de modo ilegal, de contrabando", es decir, contra la ley establecida (normalmente, para cobrar determinados impuestos). Es la única aparición del verbo correspondiente en tragedia. Sin duda, era un término corriente en la vida ordinaria de los atenienses. 


\section{Heraclidas}

1. Yolao, sobrino y fiel acompañante de Heracles otrora, y defensor de los hijos del héroe cuando se ven perseguidos cruelmente por Euristeo, afirma que para unos hijos no hay honor más hermoso que haber nacido de padre bueno y valeroso, así como casarse con una hija de padres buenos:

"Mas a quien dominado por el deseo

emparentó con malvados, no lo elogiaré:

dejarles oprobio a los hijos por causa de su placer" ${ }^{\prime 30}$.

Dos conceptos importantes nos salen al paso: el deseo (póthôi), aquí dativo de causa $^{31}$, equivalente en cierto modo a un genitivo agente, es responsable de que un varón haya sido vencido y se vea constreñido a casarse con la hija de unos malvados; todo eso crea mala fama ${ }^{32}$ a sus hijos por causa de su placer (hèdonès). En contextos como el presente, hēdonē tiene un contacto evidente con el campo semántico de la sexualidad ${ }^{33}$.

2. Macaria decide morir para salvar la vida de sus hermanos, cuando se entera de que un oráculo exigía inmolar en honor de Perséfone una doncella (parthénon) de buena estirpe (Heracl.489-90); la muchacha se pregunta, con gran sensatez, que, en caso de ser desterrados de Atenas, quién pretendería tener por esposa a una doncella abandonada o tener hijos con ella ${ }^{34}$; quiere morir en brazos de mujeres, no de hombres; hace entrega de la edad propia del matrimonio ${ }^{35}$; les pide a sus hermanos que, cuando acaben sus sufrimientos y regresen a su país, la entierren del modo más hermoso:

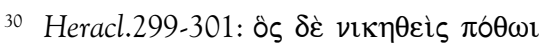

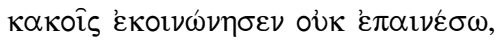

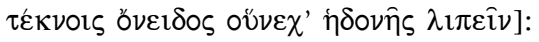

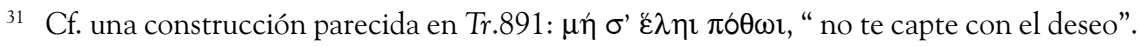

32 Atención especial merece el término óneidos.

33 Si el verbo correspondiente lo leemos desde Homero (en aoristo), el sustantivo está

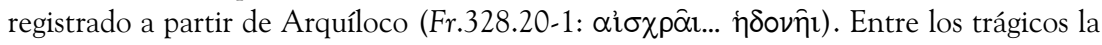
distribución es la siguiente: Esquilo (8), Sófocles (31), Eurípides (75). Lo importante en el texto que revisamos es la relación del sustantivo con la esfera del matrimonio.

34 Heracl.523-4: $\pi \alpha 1 \delta 0 \pi 01 \varepsilon i ̂ v$.

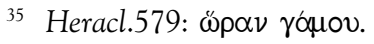


"Estas honras serán mis bienes a cambio de hijos y de virginidad, si es que hay algo bajo tierra"36.

\section{Hipólito}

1. La diosa Cipris (Afrodita) pronuncia el prólogo: expone de forma concisa y clara las causas por las que castigará a Hipólito en tal día. Ya en los primeros trímetros nos advierte acerca de sus premios y castigos:

"A quienes veneran mis poderes, respeto, y abato a cuantos se enorgullecen contra mî"37

El texto griego dice sébontas (participio de presente de sébô), es decir, la actitud del hombre piadoso hacia la divinidad y que cumple con los ritos y normas habituales y tradicionales. Téngase en cuenta que la acción contraria es la asébeia, "impiedad", condenada a veces con la muerte.

Para demostrar que son verdad sus palabras se refiere al caso concreto objeto del drama, Hipólito:

"el único de esta tierra trecenia, dice que soy la más malvada de las divinidades, rechaza el lecho y no toca la unión sexual" ${ }^{38}$.

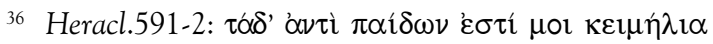

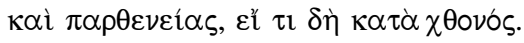

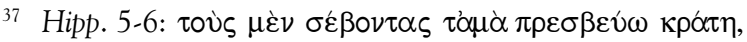

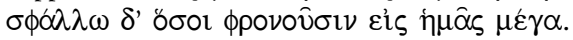

Cf. para la actuación de la diosa Hipp. 443-6, donde de nuevo leemos el castigo de quienes se muestran soberbios ante ella:

"Cipris no es soportable, si violenta se lanza.

Ella que, a quien cede, con dulzura lo visita, mas, a quien altivo y desdeñoso encuentra, apoderándose de ése - icómo crees? - lo atormenta”.

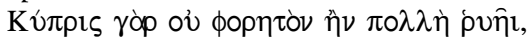

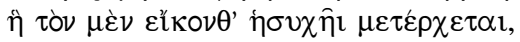

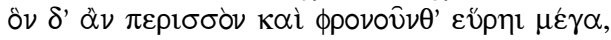

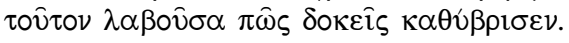

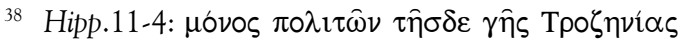

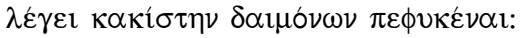

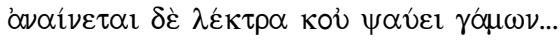


Me centraré en un concepto esencial: gámos. Desde Homero son normales tanto el sustantivo como el verbo correspondiente, gamé $\hat{o}^{39}$. Ciñéndonos a los versos expuestos, la acción de rechazar, desdeñar, propia de anaínomai, no puede ser el lecho como lugar material donde se descansa y duerme, sino las actividades que se llevan a cabo en tal lugar y que tienen que ver con Cipris, en sentido amplio. Por otra parte, el complemento de psaúô, "tocar, palpar", es gámôn, genitivo propio; su significado normal, especialmente en plural, es "matrimonio", por lo que varios críticos lo entienden así. Pero la diosa no se queja de que Hipólito se abstenga del matrimonio, es decir, esté soltero, sino de su castidad, o lo que es igual, que no practique lo que es habitual en un matrimonio.

2. Hipólito, tras unas palabras dirigidas a sus compañeros cazadores, expone de forma paradigmática su modo de ser y pensar. Se dirige a Ártemis, a la que le lleva una corona adornada con flores de un "prado intacto" (ex akērátou / leimônos); sólo la primaveral abeja lo recorre; Vergüenza ${ }^{40}$ lo cuida con rocíos fluviales; los que nada han aprendido, sino que de nacimiento obtuvieron la suerte de ser castos (sôphroneîn) en todo, de idéntica forma, pueden recoger sus frutos, pero a los malos no les es lícito ${ }^{41}$.

Difícilmente puede expresarse con menos palabras la ideología y modo de ser del protagonista. Algunos términos nos obligan a detenernos.

39 De la importancia de ambos en los trágicos nos da idea el simple recuento numérico: Esquilo, 46-10; Sófocles, 27-3; Eurípides, 199-62 (En cambio, Aristófanes: 16-8).

40 Desde Homero, $\alpha \grave{\delta} \delta \omega ́ s$ es un sustantivo de uso normal. Lo tenemos claramente personificado en Hesíodo (Op.200); en los trágicos la distribución es como sigue: Esquilo (12), Sófocles (4), Eurípides (38). En nuestro poeta encontramos algunos ejemplos en

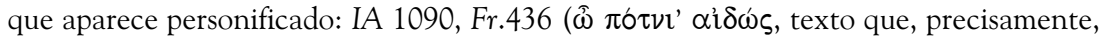
procede del Hipólito no conservado).

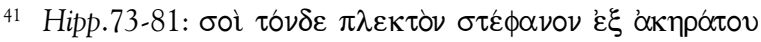

$\lambda \varepsilon 1 \mu \omega \hat{\omega} \nu \varsigma, \hat{\omega} \delta \dot{\varepsilon} \sigma \pi \circ \nu \alpha, \kappa \circ \sigma \mu \eta \dot{\eta} \sigma \alpha \varsigma \phi \dot{\varepsilon} \rho \omega$,

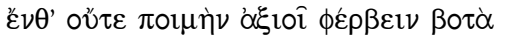

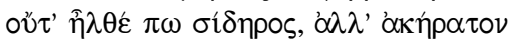

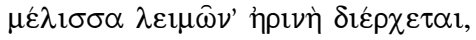

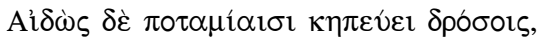

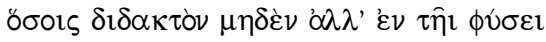

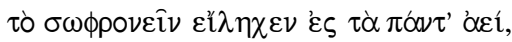

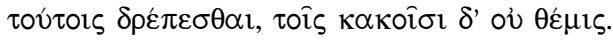

Este texto, de gran riqueza léxica, merece un comentario extenso y detenido que no puedo hacer ahora. 
En primer lugar akēratos. Desde Homero sirve para calificar al agua, vino, oro, etc. de calidad pura; pero, a veces, añade una connotación especial: "intacto". La etimología no está bien establecida, ni es clara su relación con keránnymi, "mezclar".

Nótese en el texto la posición enfática, final de verso $(73,76)$ de tal adjetivo y su concordancia en ambos casos con "prado". Un leimôn es, en el caso de esta tragedia, un recinto sagrado, una especie de témenos, junto al mar Sarónico. Es muy posible que sólo a los devotos de Ártemis se les permitiera el acceso a tal lugar así como coger flores en el mismo. Pero un punto clave del pasaje es la exclusión de quienes no obran de la misma manera que el protagonista, a saber, el que no es "casto". Efectivamente sôphrôn, y el verbo correspondiente (sôphroneîn) son usados con frecuencia en Hipólito con el sentido, respectivo, de "casto", "ser casto".

Podría hacerse un excurso tanto sobre la importancia de la phýsis en este pasaje $^{42}$ en abierta oposición a algunas ideas avanzadas sobre la enseñanza y el aprendizaje ${ }^{43}$, como acerca de la posible presencia de teorías habituales en ciertos círculos como los órficos con quienes se ha pensado que podía estar relacionado el protagonista (cf. Hipp.952-5).

Versos más abajo, cuando el sirviente le pide a Hipólito que salude la imagen de Afrodita situada junto a la puerta de la mansión, he aquí la respuesta del héroe, con la que subraya su modo de ser: "Siendo casto, desde lejos la saludo". ${ }^{44}$

Desde Homero hagnós es utilizado para calificar a los dioses; posteriormente se aplica también al éter y a los ríos. El sentido esencial es el de "sagrado", pero tiene indudable importancia otro matiz: "casto". Los trágicos lo emplean con frecuencia ${ }^{45}$.

Por otra parte, a Hipólito no le agrada una divinidad que es admirada por la noche ${ }^{46}$.

42 Poner la phýsis como fuente única de virtud equivale a aceptar las ideas aristocráticas de un Píndaro, por ejemplo, para quien se es todo por nacimiento y naturaleza. Precisamente, la frase "en todo, siempre" subraya esa creencia en los valores sempiternos propios de la naturaleza peculiar de un grupo especial. Aquí, desde luego, se hace referencia a los seguidores de la diosa Ártemis.

43 Cf. Demócrito (68 B 33 D.): "la naturaleza y la educación son algo semejante. Pues también la educación le altera el ritmo al hombre, y, al alterarlo, crea naturaleza” († $\phi v ́$

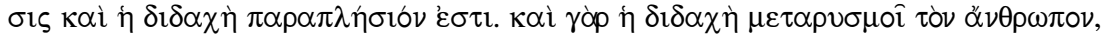
$\mu \varepsilon \tau \alpha \rho v \sigma \mu о \tilde{\sigma} \sigma \alpha \delta \dot{\varepsilon} \phi v \sigma 10 \pi \circ 1 \varepsilon \hat{\imath})$.

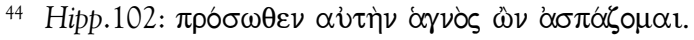

45 Esquilo (34), Sófocles (8), Eurípides (32). Precisamente, en Hipp. lo leemos 6 veces.

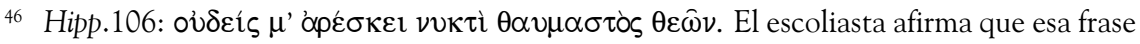
equivale a "realizar el acto venéreo ( $\alpha \phi \rho \circ \delta ı \sigma i \alpha \zeta \varepsilon \imath v)$ ". 
3. El Coro, en la párodo, alude a la postración enfermiza de Fedra: no sale del palacio, lleva la cabeza cubierta con velos ligeros, hace tres días que no come, quiere morir. Se pregunta por las posibles causas de ese estado: en primer lugar, divinidades o seres asimilados (Pan, Hécate, Coribantes, Ártemis) que hacen pensar en una enfermedad mental ${ }^{47}$. Y, luego, apunta a otro motivo que podría explicar la situación de la reina:

" $i O$ de tu esposo, señor

de los erectidas, el de ilustre progenie, alguien se ocupa, dentro de tu morada, en cama oculta a tu lecho?" ${ }^{48}$.

Realmente son dos sustantivos que aluden al lecho: uno, koíta (koítē en ático) ${ }^{49}$, otro, léchos, aquí en plural, número en que suele traducirse por "matrimonio". La idea esencial es que el soberano mantendría una relación adúltera dentro del hogar (en oíkois); esa unión sexual sería ajena, realizada en lugar apartado, y, en todo caso, lejos de la vista de la esposa; el griego utiliza el genitivo de plural (lechéôn sôn), genitivo ablativo regido por kryptâi $i^{50}$.

El escoliasta ha notado bien que se está hablando como si Teseo tuviera una concubina, $y$, añade, que el Coro parece no darse cuenta de que el rey está fuera de Atenas, pues habla en presente como si en ese preciso momento tuviera lugar tal relación adúltera.

47 La nodriza apunta también a la locura: manía (214), paráphrôn (232), parakóptei phrénas (238: piénsese que parakopê, parákopos son términos utilizados por los médicos para referirse a los trastornos mentales); alude, asimismo, a la enfermedad: nósoi (176), noserâs (179), noseîn $(186,279)$, nosê̂s ti tôn aporrêtôn kakôn (293); y a desear de modo apasionado, érasai $(225,235)$. Fedra menciona también su trastorno: pareplágthên gnômês agathês (241), emánên (241), tò mainómenon (248). El Corifeo subraya la afección de la reina: nósos (269), plánon phrenôn (283).

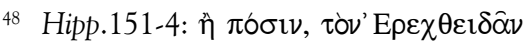

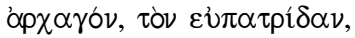

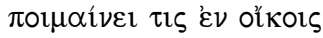

$\kappa \rho v \pi \tau \hat{\alpha} \mathbf{l} \kappa o i ́ \tau \alpha \mathbf{l} \lambda \varepsilon \chi \dot{\varepsilon} \omega \nu \sigma \omega \hat{\nu}$;

49 He aquí el número de veces en que lo usan los trágicos: Esquilo (2), Sófocles (8), Eurípides (22). En Homero sólo está registrado una vez (Od.19.34).

${ }^{50}$ La atención especial que Eurípides le dedica al adjetivo kryptós resulta evidente al comprobar el número de ocasiones en que es usado por los tres trágicos: Esquilo, 1, Sófocles, 2, Euripides, 23. En Homero (1) y Alceo (1) están los precedentes literarios.

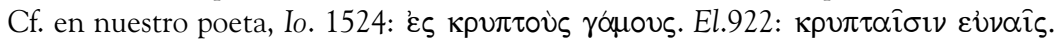


4. Cuando la nodriza consigue que Fedra hable algo, ésta, entre otras frases, pronuncia la siguiente: "iOh madre desdichadísima! iQué deseo deseaste!"

De los cincuenta y tres usos de eráô-éramai en nuestro poeta, quince los tenemos en la tragedia que revisamos. La construcción, el acusativo interno y etimológico, la referencia al toro, todo ello confiere fuerte valor erótico-sexual al pasaje.

Fedra, tras referirse a la enfermedad ${ }^{52}$ que tiene (érôs como afección), expone una máxima de carácter general:

“(...) Así hubiera perecido de modo horrible

la primera que comenzó a deshonrar el lecho con varones ajenos $(. .) "$.53 .

Es la primera vez que tenemos en la literatura griega la fórmula en optativo cupitivo (irreal de pasado) "así hubiera perecido" o "muerto", expresión que tuvo mucho éxito en la literatura griega y latina de épocas posteriores.

Fedra se está remontando a lo que podríamos llamar la prôtē heurétis, primera descubridora, de la infidelidad conyugal.

Un escolio oportuno comenta que, según Herodiano, las primeras que se prostituyeron fueron las hijas de Eurípilo, no el de Cos, sino algún otro; y sus nombres eran Forma y Famosa (Morphē y Klytēe $)^{54}$, nombres parlantes quizá.

La deuteragonista sigue afirmando que el mal, es decir, deshonrar el lecho, comenzó a darse entre las mujeres de nobles mansiones. Y así, cuando a las personas elevadas les parece bien lo infame, las bajas creerán que es hermoso. Sostiene que odia a las que son castas (sôphronas) en sus palabras, pero ocultamente tienen atrevimientos no buenos ${ }^{55}$.

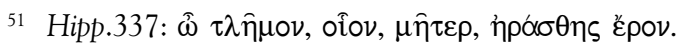

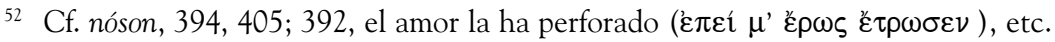

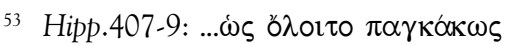

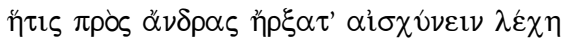

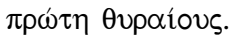

54 Cf. Herodiano gramático, Monobiblo sobre nombres propios,2.1.

55 Hipp.414: tólmas ou kalás. En contextos como éste, tólma es algo más que "atrevimiento", "osadía”, pues corresponde al plano sexual. Efectivamente, leemos a continuación (Hipp.415-8): 
5. Una vez que Fedra ha confesado estar enamorada ${ }^{56}$ del hijo de la Amazona, la nodriza ${ }^{57}$ expone los poderes de Cipris que va y viene por el éter y reside en las olas del mar; de ella surgió todo; siembra el amor. Un día Zeus deseó la unión sexual con Sémele (Hipp.453-4: èrásthē gámôn/Semélēs).

La nodriza se pregunta cuántos maridos, estando en sus cabales, viendo sus lechos deshonrados ${ }^{58}$ aparentaron no haberlos visto; y cuántos padres han ayudado a Cipris cuando sus hijos cometían una falta (en sentido sexual, sin duda). Insiste en la enfermedad de Fedra ${ }^{59}$ y en que ésta tiene necesidad del varón (Hipp.491: andrós), al que hay que contárselo todo. Para tal afección existen conjuros y palabras hechiceras; además, sabe de filtros (phíltra) ${ }^{60}$ que hechizan el amor, pero es preciso apoderarse de un mechón de los cabellos o de un jirón del peplo del amado para lograr un único amor a partir de dos. Y añade:

"Si tu vida no estuviera en trance

tal, y resultaras ser mujer casta,

no, por causa de tu lecho y tu placer,

te empujaría yo allí (...)" ${ }^{\prime 1}$.

"Las cuales, ¿cómo,ioh soberana Cipris, marina!, miran al rostro de sus compañeros de lecho,

y no sienten escalofríos de la oscuridad cómplice

y los techos de su mansión, por si cobraran voz ?".

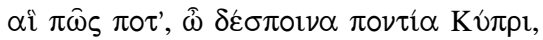

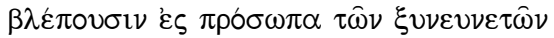

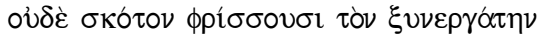

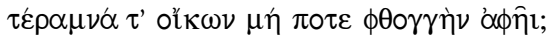

56 Pregunta primero qué es "amar" (erân, 347); la nodriza le pregunta si está enamorada (erâis; 350), y luego lo confirma (439).

57 Con sutiles razones, como la de que morir por causa del amor (érôtos) no les interesa a los amantes (tô̂s erôsi) (440-1).

58 En 463 se habla de nosoûnth'...léktra, es decir, "lechos enfermos", con lo que hace referencia a la enfermedad amorosa que afecta a quienes se sirven de esos lechos.

59 Hipp.477 (nosoûsa...nóson), 479 (phármakon nósou).

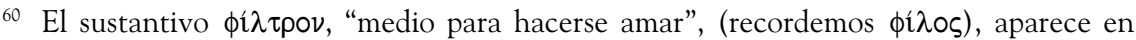
Simónides (1); luego, en Esquilo (1), Píndaro (2), Sófocles (2: Tr.584, 1142 ) y Eurípides (16).

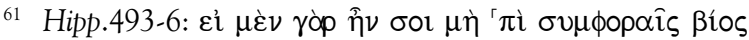

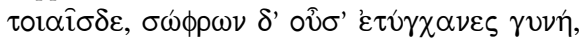

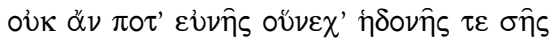

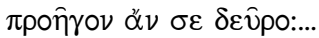


Nos interesa aquí, de nuevo, el concepto de "casta", donde ha habido un desplazamiento desde la condición mental ("sao-phrôn, "mente sana", "sensato", "prudente") hasta el campo sexual.

Por otra parte eunē tiene un valor amplio en casos como éste: tanto puede referirse al lecho matrimonial como al que quisiera compartir con Hipólito; en todo caso, está claro que la enfermedad de Fedra está íntimamente relacionada con el "lecho". Además, viene todo ello reforzado con la presencia de hēdonē, concepto grato a nuestro poeta ${ }^{62}$ y que tiene ciertos contactos con el campo semántico de la relación amorosa (cf. Heraclidas 299-301).

6. Contra el parecer de Fedra, la nodriza, haciéndole jurar de antemano que guardará silencio, le cuenta a Hipólito lo que le ocurre a su señora. Sabemos todo eso de modo indirecto, ya que el héroe tiene una reacción terrible en que maldice a las mujeres, y afirma que, de modo especial, odia a la mujer sabia (Hipp.640), pues Cipris infunde malicia en las que son tales; añade que la nodriza había llegado para conseguir una unión en el lecho intocable de su padre (es decir, le habría sugerido, pura y llanamente, unirse con Fedra en el lecho matrimonial); sostiene que se purificará lavándose los oídos con agua clara, pues, tan sólo con oír tales palabras, cree no estar puro (Hipp.655: hagneúein).

7. Cuando Fedra se ha ahorcado, Teseo, que acaba de llegar y sólo sabe que su esposa se ha suicidado, al ver la tablilla suspendida de la mano de ésta, afirma:

"iTen confianza, desdichada! Ni al lecho de Teseo ni a su mansión hay mujer que vaya a entrar" ${ }^{63}$

Hay ciertos paralelos con el pasaje en que Alcestis se despide de Admeto; tanto aquí como allí, la última voluntad de la esposa (muerta aquí, viva todavía allí) sería que su esposo no volviera a casarse. El orden de palabras parece indicar que lo primero es que nadie entre al "lecho" de Teseo; lo segundo, a la mansión.

8. Teseo le cuenta al Corifeo que:

${ }^{62}$ Esquilo, 8 apariciones; Sófocles, 31; Eurípides, 75 (En Aristófanes, en cambio, sólo 8).

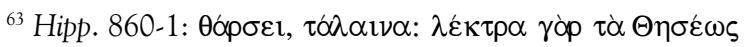

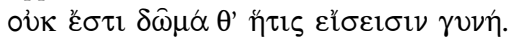


"Hipólito mi lecho osó tocarlo

con violencia, la venerable mirada de Zeus ${ }^{64}$ menospreciando" ${ }^{65}$.

Propiamente, no es el "lecho", sino la que estaba en el lecho, es decir, la esposa. Tal metonimia es frecuente en nuestro autor. Subrayemos la idea de "violencia" (bía), especialmente castigada por la ley ateniense.

Teseo articula bien su acusación y duda de la vida casta de su hijo:

"Mirad a éste, que, aun nacido de mí, mancillaba mi lecho y es acusado por la muerta, a las claras, de ser malvadísimo” ${ }^{\# 6}$. (...) "iTú casto y sin mezcla de maldad?"

iEs que la locura amorosa en los varones no existe, mas, por natura, en las mujeres se da? Conozco yo a jóvenes, en nada más seguros que mujeres, cuando perturba Cipris su joven corazón” ${ }^{68}$.

9. Frente a lo afirmado por su padre (que parte de las palabras insidiosas escritas por Fedra en la tablilla antes de quitarse la vida), Hipólito se defiende con todos los recursos de que es capaz:

"Intacto estoy en lo que crees haberme cogido ahora;

del lecho, hasta este instante del día, puro está mi cuerpo.

No conozco este comercio, salvo oírlo de palabra

64 Desde Hesíodo, Op.267, tenemos la imagen del ojo de Zeus que todo lo ve.

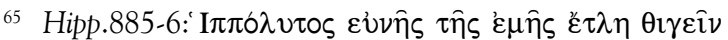

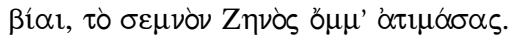

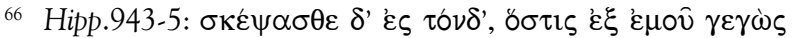

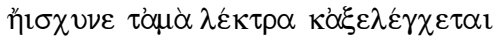

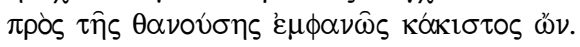

Teseo repite en la pieza la mancilla de su lecho, la deshonra y la violación llevadas a cabo por Hipólito: 944, 946, 1040 (atimásas), 1068, 1073, 1165,1266,

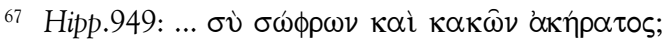

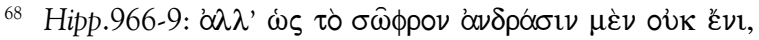

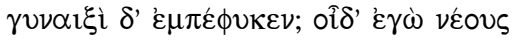

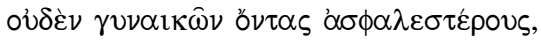

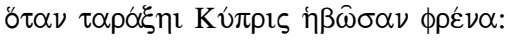


y verlo en pintura. Eso, ni de contemplarlo deseoso estoy, manteniendo alma virgen.

Mi castidad no te convence:iBien!

Debes, entonces, demostrar de qué modo me corrompí.

¿Acaso el cuerpo de ésta era hermoso

entre todas las mujeres?(...)

Ahora, por Zeus juramentado y el suelo del país, juro no haber tocado jamás a tu esposa

ni haberlo deseado ni concebir el propósito (...)

Fue casta la que ser casta no podía,

y yo que podía, no lo aprovechaba bien" ${ }^{99}$

Por limitarnos a lo más relevante subrayo, en el texto griego, y enumero aquí varios conceptos que tienen evidentes connotaciones sexuales y que no puedo comentar como sería necesario: áthiktos, "no tocado", "intacto"; léchous; hagnón, "puro, santo"; prâxin, "acción", "comercio sexual"; parthénon ("pura", "virginal"); sôphron (como el verbo citado después, con sentido sexual: "casto"); diephthárēen; hápsasthai gámôn; esôphrónēsen-sôphroneîn.

10. Teseo manda al exilio a su hijo, aunque ya antes le había pedido a Posidón que lo matara en aquel mismo día (Hipp.889-90). Una vez más, el carácter indomable, orgulloso del protagonista, se pone de manifiesto:

"Si tú fueras mi hijo y yo tu padre, te habría matado, no te condenaría con destierro, si creyera que habías tocado a mi esposa"70.

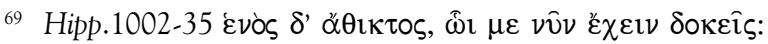

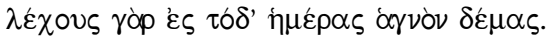

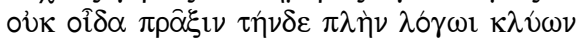

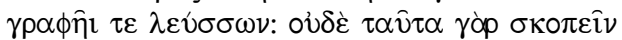

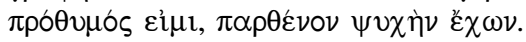

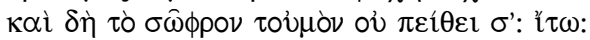

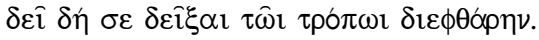

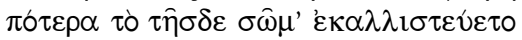

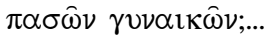

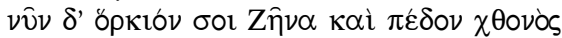

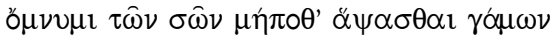

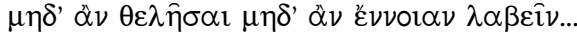

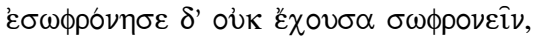

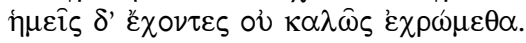

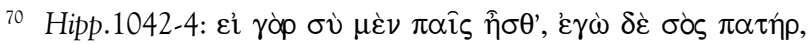


11. Condenado al exilio, Hipólito pregunta a la mansión de qué huésped habrá de acudir. Su padre le replica:

"A la de quien huéspedes seductores de mujeres

guste de albergar y copartícipes de sus maldades"71

Aquí convendría detenerse en el adjetivo lymeôn, poco usado ${ }^{72}$.

12. Ártemis, dea ex machina, se muestra ante Teseo; en pocas palabras explica la verdad de lo que le ha ocurrido a Hipólito, apuntando claramente a Fedra:

“(...) De la más odiosa de las diosas

para quienes tenemos placer en la virginidad, por los aguijones de ésa mordida, se enamoró de tu hijo"73

La divinidad, al propio héroe ya agonizante, le confirma quién ha sido la autora de su desgracia: "Se quejó por su honra y te odió por casto"74.

La recompensa de Hipólito será que, en lo sucesivo, las doncellas no sometidas a yugo (ázygoi), antes de su boda, se cortarán los cabellos en su honor y el héroe recogerá las lágrimas de las mismas. De ese modo el deseo erótico de Fedra no caería en el olvido.

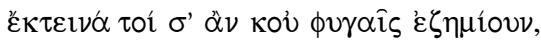

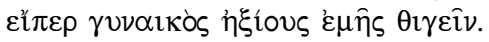

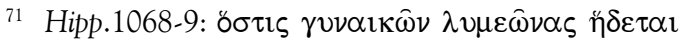

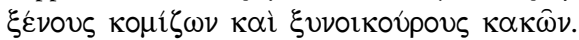

72 Sófocles (1), Eurípides (2), Jenofonte (1), Timoteo (1), Isócrates (2). Está relacionado con lwma, lýmê, y el verbo lymaínomai, "maltratar, destruir".

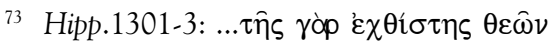

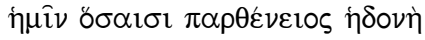

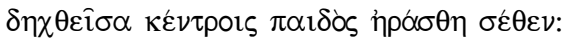

De los tres lugares subrayados el que merece un comentario más extenso es el primero. A grandes rasgos, podemos interpretarlo diciendo que los seguidores de Ártemis, a saber, quienes tienen placer virginal (por el hecho de mantener su virginidad) son los que odian muchísimo a Afrodita.

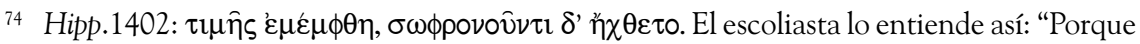
me honrabas, recibiste censura de parte suya. O porque no la honrabas totalmente". 


\section{Andrómaca}

1. La protagonista, en el prólogo, afirma que llegó al palacio de Príamo como "esposa criadora de hijos dada a Héctor" 75 . Un comentario detenido merece el sustantivo dámar ${ }^{76}$, "esposa". En tragedia tiene el valor de esposa legítima, con una ligera oposición semántica respecto a gynē, que es el término general. Eurípides usa el vocablo con bastante libertad, hasta el punto de ser una simple alternativa del último mencionado. No obstante, de vez en cuando pone el acento en el valor tradicional de "esposa legal". Nótese en este pasaje cómo se subraya la situación legal de esposa cuando vivía en Troya, frente a lo que sucede en el resto de esta tragedia, donde Andrómaca es concubina de Neoptólemo ${ }^{77}$.

Leemos en los versos siguientes, en efecto, que fue traída a la Hélade cual esclava, aun siendo de mansión muy libre, entregada a Neoptólemo como premio otorgado a su lanza, elegido entre el botín de Troya.

"Yo, en esta mansión, un retoño varón paro, unida al hijo de Aquiles, mi señor"

Podemos fijarnos en el eufemismo platheîs', es decir, "estando cerca de", con el valor de tener trato sexual. Eurípides es el primero en usar la expresión ${ }^{79}$, y el único trágico en hacerlo.

Andrómaca esperaba encontrar alguna ayuda en algún momento, pero ahora no ve la salida de su situación:

"Mas una vez que con la laconia Hermíone se casa, rechazando el señor mi lecho de esclava,

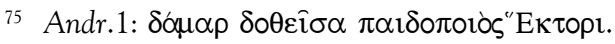

76 Aparece pocas veces en la épica y lírica. En Homero (5) lo tenemos dos veces para referirse a Penélope, la esposa de Odiseo (Od.20.290; 24.125); en los trágicos el aumento de usos es significativo: Esquilo (4), Sófocles (9), Eurípides (120). Etimológicamente está en conexión con dómos, "casa”. Término poético, el único prosista que lo utiliza en el siglo V a. C. es Lisias (1).

77 Para referirse a una concubina, desde Homero contamos con el sustantivo pallakís, y, a partir de Heródoto y de los oradores tenemos pallakê. Ninguno de esos términos es utilizado por los trágicos.

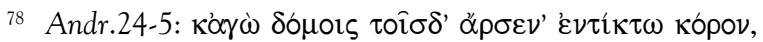

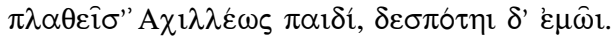

79 La utiliza en cuatro ocasiones. 
por ella, con terribles desdichas, me veo perseguida.

Afirma que, con fármacos ocultos,

la tengo sin hijos y odiada por su esposo;

y que yo deseo habitar esta morada en vez de ella,

expulsando su lecho por la fuerza;

el cual, al principio, no de grado acepté,

y ahora lo he abandonado.iZeus grande sépalo:

que no de grado en este lecho tomé parte!" ${ }^{80}$.

Sólo la acumulación de los términos léchos y léktra indica el grave problema conyugal. Frente a todas las infamias de Hermíone, la protagonista subraya que se vio sometida a unirse a Neoptólemo por la fuerza, no por propia voluntad. Sin duda es relevante la idea de que una esclava pueda ejercer violencia (bía) sobre su señora. En el plano estilístico, debe subrayarse la repetición de "no por mi grado" (ouch hékousa).

2. Andrómaca, en su lamento en metro elegiaco, habla de Helena:

"A la elevada Ilio, Paris, no esposa, mas ceguera de lecho a su tálamo llevó: a Helena"

Obsérvese la concentración de términos referidos, o próximos, a la esfera sexual: gámos- eunaía-thálamos. Por otro lado, áte $e^{82}$. Con todos ellos se insiste en el rapto de Helena y la calamidad que supuso para helenos y troyanos.

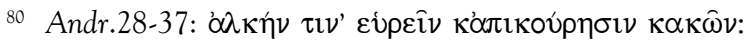

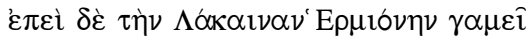

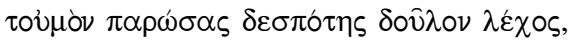

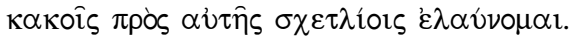

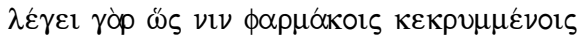

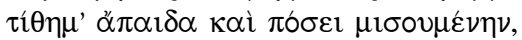

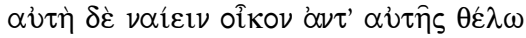

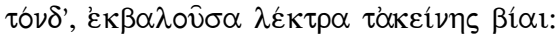

'ó

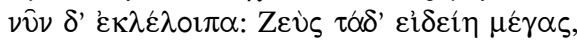

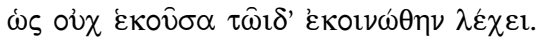

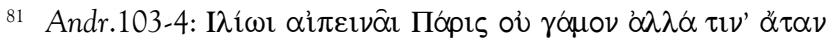

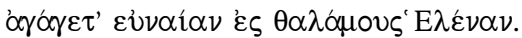

82 De una comparación con Homero (23), Esquilo (18), y Sófocles (18), resulta relevante la poca presencia en Eurípides (10). 
3. El Coro, en la párodo, menciona la desgracia compartida respecto al "matrimonio doble" con el hijo de Aquiles (Andr.123-5). El texto habla de léktrôn didýmôn, "lechos dobles". Es de suponer que, como vimos en Hipólito ${ }^{83}$, en el palacio de Neoptólemo, aparte del lecho matrimonial, hubiera una cama especial donde dormía Andrómaca. Pero puede tratarse, asimismo, de "dos esposas". El pasaje ha sido mal transmitido, es difícil y contiene varios problemas léxicos.

4. Hermíone, nada más aparecer en escena, muestra su carácter soberbio y despótico; insiste, después, en que es odiada por su marido por culpa de las drogas de Andrómaca, y que su vientre es estéril (nēdós d'akýmôn) a causa de la esclava.

"A tal punto llegas de insensatez, desdichada de ti, que con el hijo del padre que mató a tu esposo osas acostarte y de un asesino parir hijos.Tal toda la raza bárbara.

Un padre con la hija se mezcla, y el hijo con la madre, y la muchacha con el hermano (...)

(...) No es bueno que un solo varón tenga las riendas de dos mujeres, mas, mirando a una sola Cipris patrona del lecho, aman cuantos quieren vivir sin maldad" 84

Conceptos de singular relieve para nuestro estudio son xyneúdein, "dormir junto a", mígnytai, "se mezcla", hēnías, "riendas", eunaía, varias veces vista. Interés conspicuo ofrece la mención del incesto entre bárbaros ${ }^{85}$, tema de singular relieve a lo largo del siglo $\mathrm{V}$ a.C.

83 Hipp.151-4; allí pura sospecha.

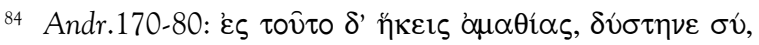

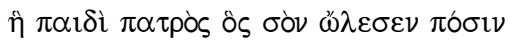

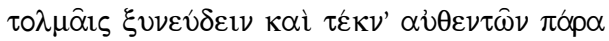

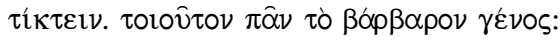

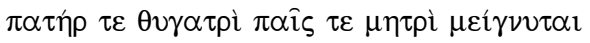

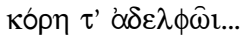

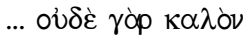

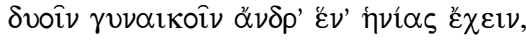

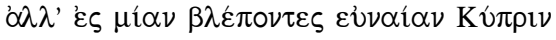

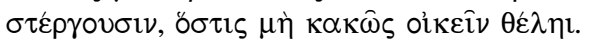

85 Heródoto, 1.135, afirma que los persas se unen con sus hijos por haberlo aprendido de los griegos; en 3.31 habla de la unión de Cambises con su hermana. Por su parte, Janto 
5. El Corifeo, (mejor dicho, la Corifeo: una mujer ptía), advierte bien por cómo surgió la polémica de las dos mujeres:

"Envidiosa es la mente femenina

contra quienes comparten su matrimonio, y, en sumo grado y siempre, hostil" ${ }^{16}$.

El término relevante es xyngámoisi ${ }^{87}$, es decir, los que están casados, o unidos, al mismo tiempo, con otro.

6. La protagonista recurre a todos los recursos retóricos de que es capaz con tal de echar por tierra los argumentos de su señora ${ }^{88}$; manifiesta orgullo y dignidad; sus palabras hieren sin duda a su rival. La finalidad está clara: despertar los sentimientos de apoyo por parte de los espectadores, al mismo tiempo que les agudiza el sentido crítico.

"No por causa de mis drogas te odia tu esposo, mas no eres apta para la vida conyugal.

Un filtro también es esto: no la belleza, oh mujer, sino las virtudes agradan a los compañeros de lecho (...)

$\mathrm{Si}$, de Tracia la recubierta de nieve

al rey tuvieras por marido, allí donde, por turno, el lecho se lo ofrece a muchas, compartiéndolo, siendo él uno solo, ¿las habrías matado? Además, de insaciabilidad de lecho se vería que acusas a todas las mujeres.

iVergonzoso! Más grave que los varones esa enfermedad padecemos, aunque bien nos libramos. ¡Oh queridísimo Héctor! En gracia a ti, amaba yo

de Lidia (Fr.31) observa que los magos se acuestan son sus madres. Los Argumentos dobles (Dissoì lógoi) (cf. D.-K. 2. p. 408) nos recuerdan que para los persas es buena la relación sexual con la hija, madre y hermana.

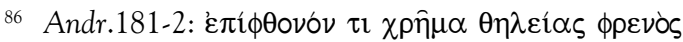

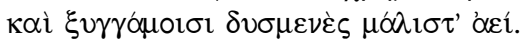

87 Eurípides es el primero en usar el adjetivo $s(x)$ ýngamos (5) y el único que lo hace hasta fines del $\mathrm{V}$ a.C.

88 En casos como éste el debate se convierte en un verdadero agón judicial, como los que leemos en Hec.1129 ss (Poliméstor-Hécuba, ante Agamenón) o Tr.895 ss ( HelenaHécuba, en presencia de Menelao). 
al mismo tiempo que tú, cuando Cipris te hacía cometer una falta, y el pecho, ya muchas veces, a tus bastardos ofrecí, para no causarte amargura alguna (...)

A la que te parió, en pasión por los varones, mujer, no intentes superar (...)" ${ }^{\prime 9}$

No puedo extenderme ahora en un comentario apropiado de varios términos y expresiones dignas de mayor atención: xyneînai, phíltron, xyneunétas, léchos, la oposición entre "muchas" y "uno solo", aplēstían léchous, nóson...nosoûmen, synērôn ("amar al mismo tiempo que otro"), sphálloi ("cometer falta", referido a la esfera sexual), mastón $n^{90}$, philandría ("pasión por el varón") ${ }^{91}$,etc.

7. En el agón con su señora leemos lo siguiente:

Andrómaca. - "iNo sufrirás en silencio lo relativo a Cipris?

Hermíone. - iY qué? Para las mujeres, ino es eso lo primero en todas partes?" ${ }^{2}$.

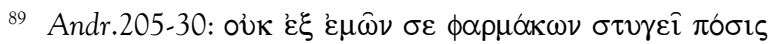

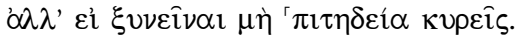

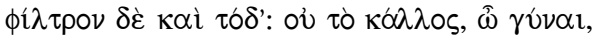

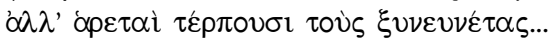

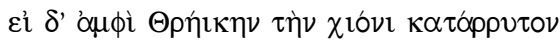

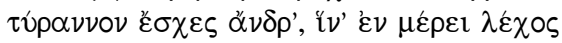

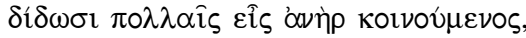

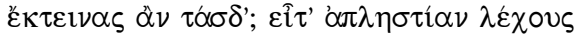

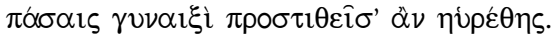

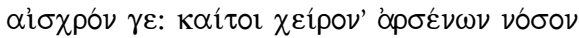

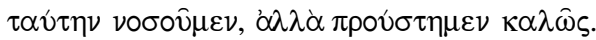

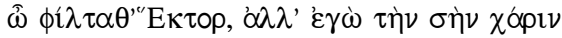

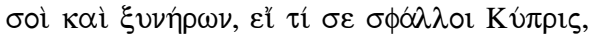

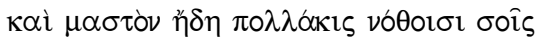

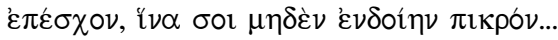

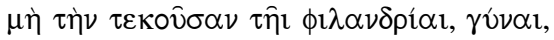
$\zeta \eta ் \varepsilon \imath \pi \alpha \rho \varepsilon \lambda \theta \varepsilon i \hat{\nu}: . .$.

90 En Il.5.70 se nos dice que Teano amamantó a un hijo bastardo de su esposo Antenor.

91 Término no empleado antes de Eurípides, donde sólo aparece en esta secuencia. No lo encontramos ya hasta Filón de Alejandría y escritores posteriores.

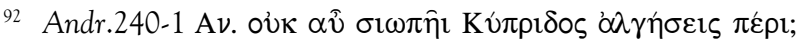

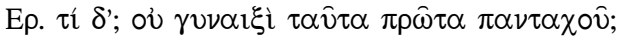


8. La protagonista sostiene ante Menelao que, si dan muerte al hijo que ha tenido con Neoptólemo, éste expulsará a Hermíone del palacio:

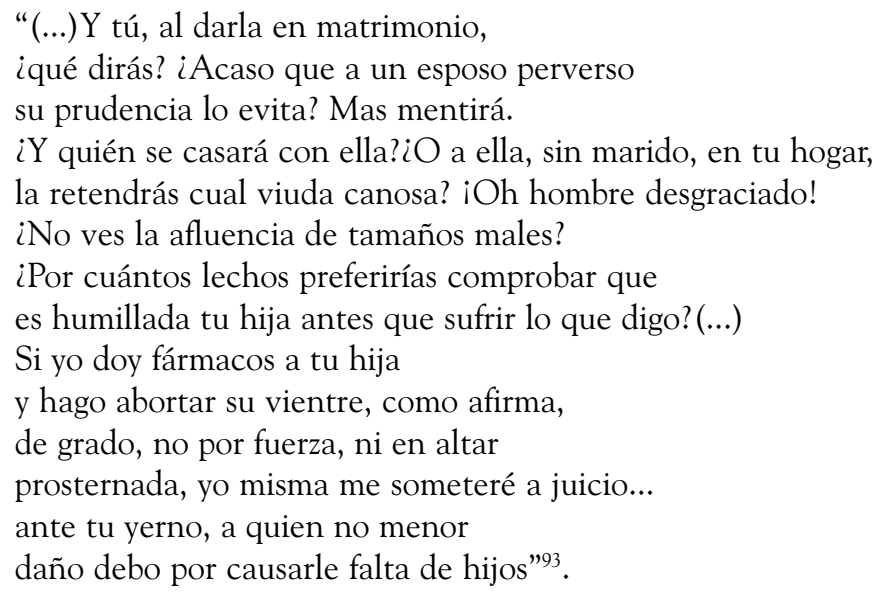

He aquí otra secuencia merecedora de un comentario apropiado. Términos y expresiones relevantes: ánandron, chēra poliós ("viuda canosa"), eunás (tanto puede ser el lecho como la que se acuesta en él; en este caso, concubina), pharmakeúô, (con el doble sentido de phármakon, "medicina"/ "veneno"), nēdón exambloûmen (donde hay que detenerse en el sentido técnico de los términos), apaidía. Además, la expresión judicial blábēn opheílô.

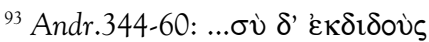

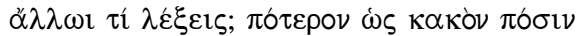

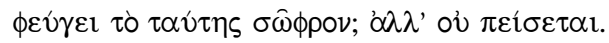

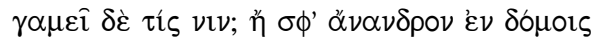

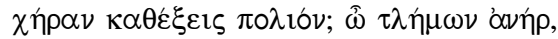

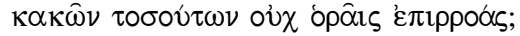

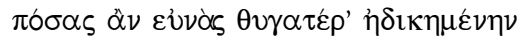

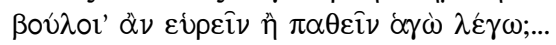

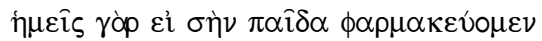

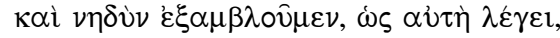

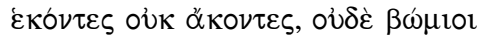

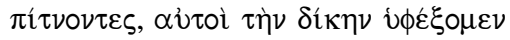

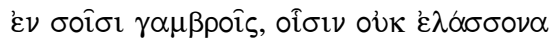

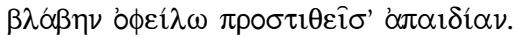


9.Menelao, entre otras razones, así le replica a Andrómaca:

"Y yo, de mi hija - pues juzgo grave esto:

ser privada del esposo- en aliado me erijo.

Lo demás cual secundario soportaríalo una mujer,

mas, fallando en su marido, falla en su vida" ${ }^{\prime 94}$.

El texto habla de "ser privada del lecho", pero realmente alude al esposo. La repetición del verbo hamartánô nos indica dónde se quiere poner el énfasis. En pasajes como éste, anēr mantiene el significado general de "varón", con un valor opuesto a mujer, y, por tanto, la máxima adquiere valor general; es decir, no sólo se trata del hombre casado, sino del varón de cualquier pareja constituida. De ese modo se añade fuerza a las palabras del actor.

10. En sus razones, Andrómaca subraya que se acostó a la fuerza con su señor (Andr.390: ekoimēthēn bíai); explica cómo, convertida en esclava, llegó a las naves de los argivos, arrastrada por los cabellos; tuvo que unirse con el asesino de Héctor (Andr.403: phoneûsin Héktoros nympheúomai).

11. El Coro, en el segundo estásimo, se expresa de este modo:

"Jamás elogiaré uniones dobles de mortales

ni hijos de dos madres,

discordias de los hogares y odiosas tristezas.

Desee mi esposo, en el matrimonio,

un lecho marital no compartido" 95

En la expresión dídyma léktra entiéndase, no "lecho", sino los que están en el lecho. Respecto a la construcción amphimátoras kórous, no son, evidentemente, niños de dos madres, sino hijos del mismo padre que viven con varias esposas del mismo.

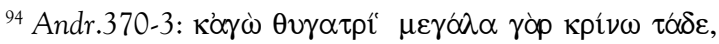
$\lambda \varepsilon \chi 0 \cup \varsigma \sigma \tau \varepsilon \dot{\varepsilon} \rho \sigma \theta \alpha \mathrm{l}) \quad \sigma 0 ́ \mu \mu \alpha \chi \circ \varsigma \kappa \alpha \theta i \sigma \tau \alpha \mu \alpha \mathrm{l}$.

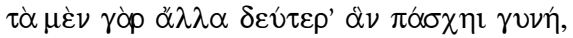

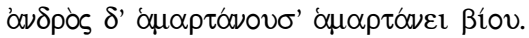

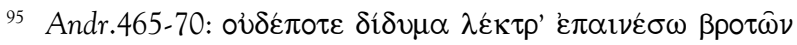

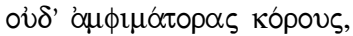

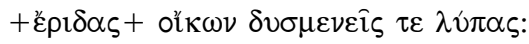

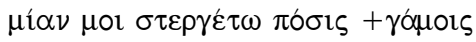

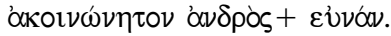


Un problema especial lo plantea el giro andròs eunán, explicado por los intérpretes como "lecho matrimonial". Hay, es verdad, ciertos precedentes (cf. Il.18.433 y Esquilo, Supp.822), pero en ellos el sujeto es una mujer: "lecho del esposo", es decir, del hombre, del varón; pero aquí el sujeto es el varón. El escoliasta y algunos comentaristas interpretan andrós como genitivo ablativo dependiente de akoinônèton, "no compartido por varón"; entiéndase, "otro varón", es decir, un lecho donde sólo hay un esposo y no dos. En ese caso, sería difícil explicar el verbo stergétô, "confórmese", "desee”. Obsérvense las posiciones enfáticas, comienzo y final de verso, de mían y eunēn, dos conceptos relevantes sobre los que se incardina el pasaje.

12. Peleo, anciano abuelo de Neoptólemo, llega en el preciso momento en que Menelao y Hermíone se disponían a dar muerte a Andrómaca y su hijito. El héroe increpa así al Atrida:

“iTú, entre los varones?iOh cobardísimo e hijo de cobardes!

¿En qué te cuadra a ti contarte entre varones?

Tú que, por obra de un frigio, perdiste a tu esposa, tras dejar sin cerrojos ni esclavos las estancias de tu hogar, como si tuvieras en la mansión mujer honrada, la peor de todas (...)" ${ }^{\prime 96}$.

Las palabras de Peleo desmontan la leyenda homérica, épica, pues al llamar "cobarde" a un héroe homérico se le insulta con el peor calificativo que podía recibir $^{97}$. Por otro lado, el sustantivo léchous hemos de explicarlo, por metonimia, no como "lecho", sino "esposa", es decir, "la que está en el lecho", conyugal, se comprende. Tanto los cerrojos como los esclavos, especialmente los eunucos, eran

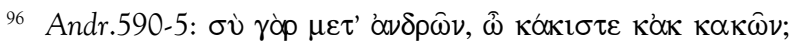

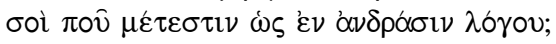

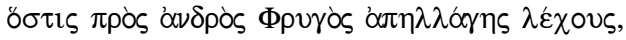

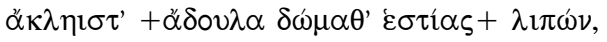

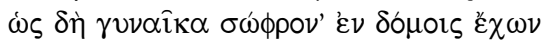

$\pi \alpha \sigma \omega \hat{\nu} \kappa \alpha \kappa i \sigma \tau \eta \nu .$.

97 En Tr. 943-4, Eurípides sigue el relato de los Cypria, tal como lo recoge Proclo (Chr. 23.98), donde se nos cuenta que Menelao se marchó a Creta y dejó a Helena sola para que atendiera a Paris y a sus acompañantes. Ahora bien, Eurípides da una paso más 
esenciales para la custodia y salvaguardia de las mansiones. El griego dice sôphron' donde he traducido "honrada"; entiéndase este adjetivo en el plano sexual.

El anciano afirma que las jóvenes espartanas no pueden ser castas, pues participan con los muchachos en carreras y ejercicios de palestra con los muslos desnudos y los peplos sueltos; además, Helena abandonó el hogar y se fue de juerga hacia otro país en compañía de un joven; a esa mujer, Menelao debía haberle escupido al ver que era una impúdica; nunca debió haber organizado la guerra contra Ilio ni pedirle a Agamenón que degollara a Ifigenia.

"iTanto temiste no recuperar a tu infiel esposa!

Tras conquistar Troya -iré allí contigo-

no mataste a tu mujer teniéndola a mano,

mas, cuando viste su pecho, tirando la espada

sus besos recibiste, acariciando a la perra traidora,

siendo vencido por Cipris,ioh cobardísimo!" ${ }^{\prime 8}$.

Varios indicios léxicos acentúan el contenido erótico-sexual del encuentro de los esposos. En primer lugar que Helena le mostrara el pecho (o los pechos) a su esposo; es un detalle más de la erotización del pecho femenino en las obras euripideas. Tanto en la Ilias parva como en Íbico se recoge la versión de que Menelao dejó las armas nada ver a Helena. En segundo lugar, la mención del beso (phílèma, puede ser beso o abrazo); en tercer lugar, la aparición de aikállô, "acariciar", usado solamente aquí en tragedia. Encontramos una imagen doble: por una parte, Helena es vista como una perra, a causa del verbo empleado, y, por otra, Menelao la acaricia como a un perro.

13. Hermíone, tras intentar ahorcarse y quitarse la vida con una espada, lanza al aire su velo vaporoso al que dirige la palabra. La nodriza le pide que se cubra el pecho, pero ella contesta:

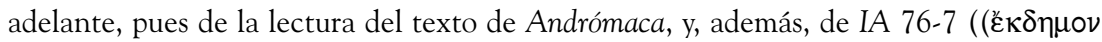

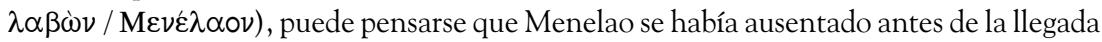
de Paris.

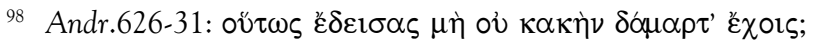

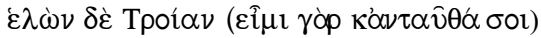

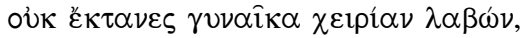

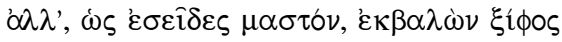

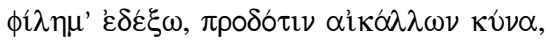

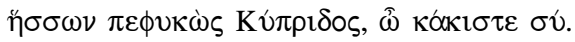


"¿Por qué debo el pecho

cubrirme con mi peplo? Evidentes,

por ambos lados visibles, no ocultos hechos

a mi esposo hice" $"$.

Es una escena de indudables resonancias cómicas y melodramáticas. Pensemos que era siempre un actor el que interpretaba cualquier papel femenino, lo que, sin duda, daría nuevos aspectos al personaje. Si Helena mostró su pecho, su seno femenino, uno solo, a Menelao, aquí su hija pretende mostrar los dos. Creo que la insistencia en los adjetivos ("evidentes", "visibles por uno y otro lado"100, "no ocultos") sustantivados que funcionan como acusativo interno de dedrákamen, es un buen indicador de que Hermíone habría desgarrado o abierto su peplo y mostraría claramente ambos senos.

La nodriza le pregunta de este modo: "iTe duele haber tramado la muerte para la compañera de matrimonio?”101. Conviene señalar que sýngamos es, normalmente, la persona, masculina o femenina, que, junto con otra, constituye una pareja, es decir, la que, con otro u otra, forma un gámos, "matrimonio", o simplemente "unión". Pero aquí no se aplica al otro componente de esa pareja, sino a la rival femenina que se une en el lecho con el marido legítimo; equivale, en realidad, a "la que comparte esposo contigo".

14. Llega Orestes que se pregunta retóricamente qué adversidad le puede ocurrir a una casada sin hijos si no es en lo referente a su esposo.

Orestes. -"iQué desdicha, si hijos aun no han

nacido, tendría una mujer salvo en lo referente a su tálamo?

Hermíone. - Esa misma afección padezco. Bien me has sonsacado.

Orestes. - ¿Algún otro lecho, en vez de ti, desea tu esposo?

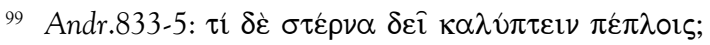

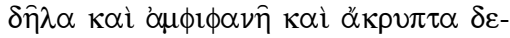

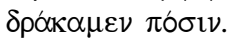

100 Adjetivo (amphiphanês) que aparece por primera vez en nuestro trágico: después de él lo emplean Aristóteles, Posidonio y otros escritores. Podría tratarse de dos puntos de vista del espectador o público, por ejemplo, el griego y el troyano; pero también cabe interpretarlo como "mostrados por uno y otro lado", o lo que es igual, cada uno de los dos senos puestos al descubierto.

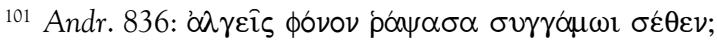


Hermíone. - A la prisionera que junto a Héctor yacía.

Orestes. - Mala cosa has dicho: que un varón tenga dos tálamos"102.

En esta secuencia hallamos una verdadera concentración léxica de términos referentes al campo que nos interesa: léchos-nosoûmen (la pasión amorosa como enfermedad)-eunēn-xyneunétin-léchēeunē-stérgei-xyneunétin-léchē. Además, gynaikí (esposa), y, por otra parte, pósis-ándra, ambos referidos al marido.

15. Hermíone alude a lo que le aconsejaban ciertas visitas femeninas. Sus palabras reflejan, con la distorsión poética pertinente, un verdadero cuadro de lo que podía pasar en Atenas por los años en que se representó esta pieza. He aquí lo que le decía alguna de esas mujeres malvadas:

"Tú, ia la malvadísima prisionera, en tu mansión, a una esclava, consentirás que contigo lecho comparta?

iNo, por la Señora! En mi hogar, al menos, viendo la luz diurna, no disfrutaría de mi lecho"103.

Otra vez la insistencia en el lecho, dos veces, y en la idea de compartirlo (koinouménēn). Realmente, se trata de compartir el esposo, no el lecho. La metonimia añade indudable fuerza dramática al texto. Al esposo seguramente se refieren las dos menciones del lecho. Por otra parte, la referencia a la luz diurna apunta a que esa mujer malintencionada daría muerte inmediata a la que quisiera acostarse con su esposo. La posibilidad de que todo ocurra en el propio hogar aporta otro detalle de elevada tensión trágica.

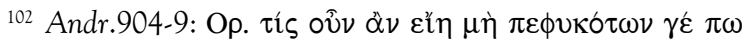

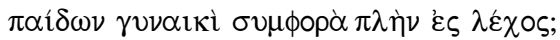

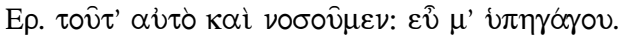

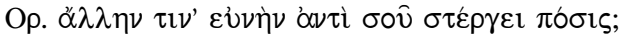

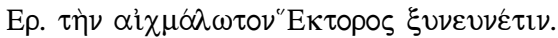

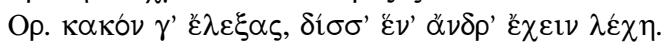

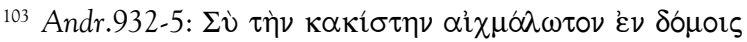

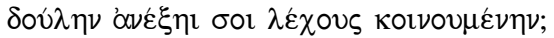

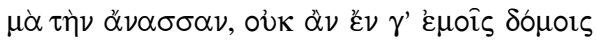

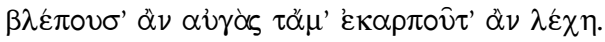




\section{Hécuba}

1. El Coro, dirigiéndose a Hécuba, recoge la disputa del ejército heleno a propósito de sacrificar o no a Políxena en honor de Aquiles:

"Defendiendo tu bien con ardor estaba quien de la divina bacante posee el lecho, Agamenón"104.

Debemos entender léktr', no como "lecho", sino, por metonimia, como la unión sexual de Agamenón con Casandra.

Los hijos de Teseo, a su vez, sostenían que "el lecho de Casandra"105 no prevalecería sobre la lanza de Aquiles. De nuevo el mismo valor que acabamos de ver.

2. Políxena, condenada a ser sacrificada en el túmulo de Aquiles, habla del terrible futuro que le esperaría como esclava en el caso de seguir con vida:

"Mi lecho, un esclavo en algún lugar comprado

lo mancillará, tenido antes por digno de reyes" ${ }^{106}$.

Entiéndase chraínô en sentido moral: es decir, un esclavo no es la persona adecuada para unirse con la hija del rey de Troya, aunque, por circunstancias adversas, sea ahora una esclava.

La joven afirma que se encamina ya a la muerte: "sin prometido, sin himeneo, los que yo debía obtener"107. Políxena habla de la muerte como la que le impide

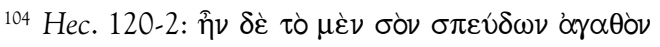

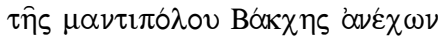
$\lambda \dot{\varepsilon} \kappa \tau \rho^{\prime \prime}$ А $\gamma \alpha \mu \dot{\varepsilon} \mu \nu \omega \nu: . .$.

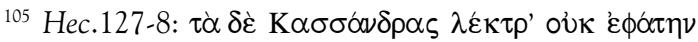
$\tau \eta \bar{\varsigma} \varsigma^{\prime} \mathrm{A} \chi \imath \lambda \varepsilon i \alpha \varsigma$

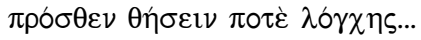

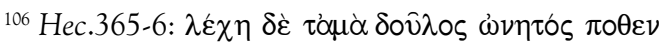

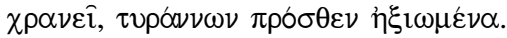

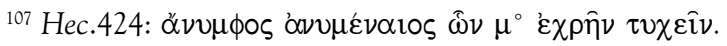


conseguir un novio, un esposo; alude, también, a los ritos que acompañan al matrimonio, especialmente el canto nupcial. En el caso de sacrificios de mujeres jóvenes, vírgenes aún, la muerte ocupa el lugar de la boda, como si se casaran con el muerto (o con la divinidad que pide la sangre virginal); ambos, en efecto, exigen sangre de doncella.

En su despedida de su madre, la muchacha dice lo siguiente: " $\mathrm{O} O \mathrm{Oh}$ pecho y senos que me nutrieron con dulzura!" 108 . Nos dice el escoliasta que la joven pronunciaría estas palabras abrazada a su madre. De otra parte, la referencia a la inutilidad de haber dado el pecho es más bien una queja propia de una madre (cf. Tr.759 ss, Supp.1136). Nótese la diferencia entre el todo, "pecho" (stérna) y la parte, "senos" (mastoí). Esa misma distribución hallamos unos versos más abajo (Hec.560).

3. El heraldo Taltibio, en su relato de la muerte de Políxena, cuenta algunas cosas pronunciadas por Neoptólemo en honor de su padre:

"Y él dijo: "iOh hijo de Peleo y padre mío!

Acéptame estas libaciones apaciguadoras, de los muertos invocadoras.iVen, a beber, de la doncella, negra y pura sangre que te regalamos el ejército y yo"(...)"109.

Observamos la presencia de varios términos de gran interés para nuestro propósito general: "libación" (choás), que nos recuerda que los muertos beben sangre (cf. Od.11.96, 153; Alc.845, 851); "apaciguadoras" (kēlētēríous), explicado por el escoliasta como hechizadoras de las almas de los muertos o de las divinidades infernales; "doncella" (kórēe), que se va a unir con la muerte; sangre "pura" (akraiphnés), término ya estudiado, donde lo relevante es la noción de pureza, ausencia de contaminación o impureza. Recordemos que, cuando en honor de los dioses o de los muertos, se sacrifica algún animal, también debe tener sangre pura, es decir, no haber parido, si se trata de una hembra, y carecer de defecto alguno.

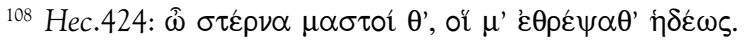

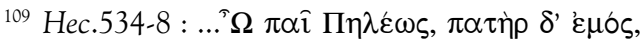

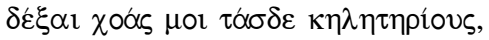

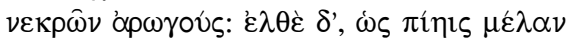

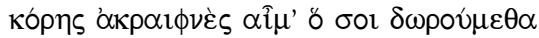

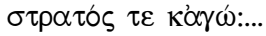


Políxena se ofreció voluntaria, sin permitir que nadie la tocara:

"Cogiendo su peplo desde lo alto de la espalda desgarrólo hasta la mitad del costado, junto al ombligo; sus senos mostró y su pecho, como de estatua, hermosísimos (...)" ${ }^{\prime 10}$.

Es la primera vez en la tragedia griega en que se compara el cuerpo desnudo con una estatua (cf. Fr.125.4; además, Queremón, Fr.1.5).

4. Hécuba habla de su hija recién sacrificada, a la que califica de este modo: "desposada sin esposo y virgen sin doncellez" (Hec.612). Era una novia, o desposada (nýmphē), en honor de un muerto concreto, Aquiles, el mejor de los aqueos. De ahí la expresión "desposada sin esposo"; su doncellez, su sangre virginal, en realidad su vida entera, ha sido ofrecida para apaciguar las exigencias de un muerto; en estos casos, la doncella mantiene su virginidad hasta el momento en que es inmolada, pues se entiende que a partir de ese instante pasa a estar casada con el muerto, o con las divinidades infernales ${ }^{111}$.

5. Hécuba, tras aparecer el cadáver de Polidoro, su hijo menor, quiere ganarse el apoyo de Agamenón para castigar a Poliméstor, el rey tracio que había dado muerte inicua al menor de los Priámidas cuando precisamente lo tenía bajo su custodia.

"Junto a tu lado mi hija se acuesta,

la poseída por Febo, a la que Casandra llaman los frigios.

¿Dónde harás ver tus noches gratas, señor,

o, por sus gratísimos abrazos en el lecho, qué favor logrará mi hija, o yo, en lugar de ella?

De la penumbra y los nocturnos encantos grandísima gratitud surge entre los mortales (...)"112.

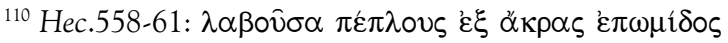

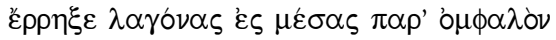

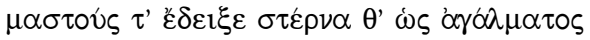
$\kappa o ́ \alpha \lambda \lambda \imath \tau \tau$...

${ }^{111}$ Cf. en nuestro poeta otras referencias: Heracl.591-2; IA 460-2; y Sófocles, Antígona 806.

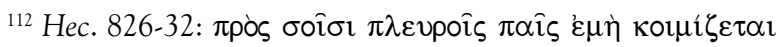

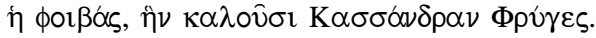


Varios términos merecen un comentario extenso: koimízô, "acostarse", uno más de los frecuentes eufemismos para referirse al acto sexual; la idea de la noche, repetida dos veces, y la penumbra, ambas propiciadoras de los encuentros sexuales, una vez acabadas las agotadoras tareas diurnas ${ }^{113}$; phílas-philtátôn-phíltrôn ${ }^{114}$.

6. El Coro, en el tercer estásimo, recoge una escena de intimidad matrimonial durante la noche en que los helenos entraron en Troya. Acabado el festín, el esposo yacía en el tálamo (thalámois) y la esposa se arreglaba las trenzas con cintas, observando los reflejos de los espejos, recostada sobre la cubierta, preparándose para meterse en el lecho ${ }^{115}$. Posiblemente, tal acción iría seguida de la unión íntima con su esposo, por lo que leemos en la antístrofa:

"El lecho amoroso, con solo el peplo, dejando, cual doria doncella (...)"116.

Hemos de pensar que el adjetivo phílios, aquí en neutro plural, referido a lecho, ha de contener algo más que la noción de amistad, para pasar al terreno de la sexualidad, tal como sucede con otros términos de su familia léxica; puede entenderse, pues, no sólo con el valor con que lo he traducido, sino también como el lecho "donde se hace el amor". Que la troyana saltó a toda prisa de donde estaba acostada, lo indica el llevar encima solamente el peplo (monópeplos $)^{117}$. Hay que tener en cuenta que el péplos es el vestido amplio, ligero, cómodo, de dimensión variada, llevado bajo otras ropas. Por la noche podía usarse

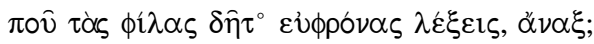

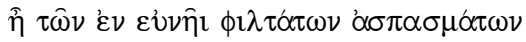

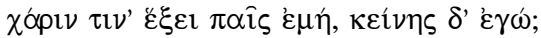

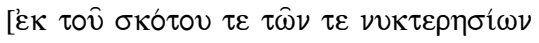

$\phi i \lambda \tau \rho \omega \nu \mu \varepsilon \gamma \hat{i} \sigma \tau \eta \eta \gamma$

${ }^{113}$ Cf. en nuestro poeta otros ejemplos: Tr.665, Ba.237, Fr.524.

${ }^{114}$ El sustantivo $\phi i ́ \lambda \tau \rho o \nu$, "medio para hacerse amar", (recordemos $\left.\phi i ́ \lambda \circ \varsigma\right)$, aparece en Simónides (1); luego, en Esquilo (1), Píndaro (2), Sófocles (2: Tr.584,1142) y Eurípides (16).

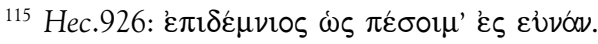

${ }^{116}$ Hec.931-2: $\lambda \varepsilon \dot{\chi} \eta \delta \dot{\varepsilon} \phi i ́ \lambda ı \alpha \mu o v o \delta \pi \varepsilon \pi \lambda \circ \varsigma$

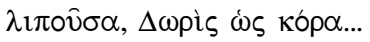

${ }^{117}$ Es la primera aparición en la literatura griega. Sólo aquí lo usa nuestro trágico: es un hápax de la literatura griega. 
como camisón. Notemos la comparación con las muchachas dorias, que, a veces, llevaban peplos cortos, sueltos, sin cinturón, enseñando los muslos y con aberturas laterales muy sugerentes; tal realidad llamó la atención de nuestro autor (cf. Andr.598).

\section{Suplicantes}

1. En la párodo, el Coro de madres suplicantes le habla a Etra, madre de Teseo:

"Pariste en otro tiempo también tú, ioh señora!, un muchacho, tras hacer amoroso tu lecho para tu esposo" ${ }^{118}$.

Hemos de entender phíla, no sólo como "grato, agradable, amistoso", sino propicio al amor y a la relación sexual. Así se explicaría mejor la voz media: poiēsámena, es decir, "hacer algo en provecho propio". La esposa, pues, habría logrado que su lecho fuera propicio para la unión sexual con su esposo, dativo aquí como régimen habitual de los adjetivos que indican "amistad" (phíla) o lo contrario.

2. Teseo, rey de Atenas, se enfrenta con el heraldo tebano: critica al tirano, defiende la democracia y las leyes escritas:

“ ¿O (sc. qué necesidad hay) de mantener vírgenes a las hijas en las mansiones, de hermoso modo, gratos placeres para tiranos, cuando guste, y lágrimas para quienes los preparan? iQue no viva yo ya, si mis hijas van a desposarse por la fuerza!"119.

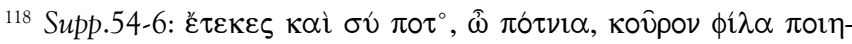
$\sigma \alpha \mu \dot{\varepsilon} v \alpha \lambda \dot{\varepsilon} \kappa \tau \rho \alpha \pi \delta \sigma \varepsilon \imath \sigma \hat{\omega} 1$ :...

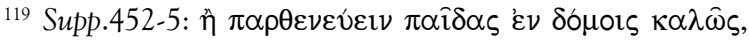

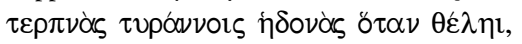

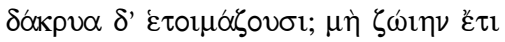

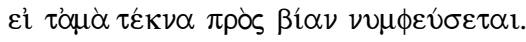


El verbo partheneú ${ }^{120}$ no vuelve a usarse en voz activa hasta Luciano. Es relevante la alusión al tirano como "desflorador de doncellas".

3. En el tercer estásimo, el Coro, como una sola voz femenina, lamenta no haberse quedado soltera, sin unión matrimonial (ágamon), pues ninguna necesidad de hijos tenía:

"iOjalá, sin matrimonio, siempre hasta hoy,

Crono, anciano padre

de los días, me hubiera dejado!

¿Qué necesidad de hijos tenía yo?

¿Qué sufrimiento enorme temía sufrir

si me libraba del yugo del matrimonio?

Mas ahora veo clarísimo

mal: de hijos queridísimos verme privada". ${ }^{121}$

La petición, en irreal de pasado, va dirigida a Crono, Tiempo. Eurípides expone en sus obras varias veces la idea de verse libre del lazo conyugal (Med.673, Hipp.125, Supp.822, IA 85).

4. El Coro, dentro del cuarto estásimo y del agón con Adrasto, afirma:

"iJamás mi cuerpo se hubiera uncido

a lecho de varón!" 122.

Estamos en la misma línea de pensamiento ya vista anteriormente.

${ }^{120}$ Lo encontramos por primera vez en Esquilo (Pr.648); luego, en Heródoto (2 veces), y en nuestro autor ( 3 apariciones). Hasta finales del $\mathrm{V}$ a. C. lo hallamos en diversos compuestos.

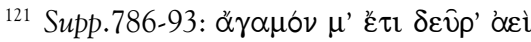

Хрóvos $\pi \alpha \lambda \alpha$ ios $\pi \alpha \tau \eta \dot{\rho}$

$\omega \phi \varepsilon \lambda ' \propto \alpha \mu \rho \hat{\alpha} \nu \kappa \tau i \sigma \alpha \mathbf{l}$.

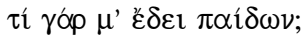

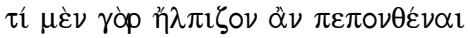

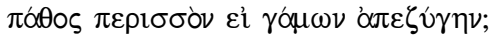

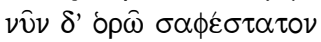

$\kappa \alpha \kappa \delta \nu, \tau \varepsilon \kappa \nu \omega \nu ~ \phi \imath \lambda \tau \alpha ́ \alpha \tau \omega \nu \sigma \tau \varepsilon \rho \varepsilon i \bar{\sigma} \alpha$.

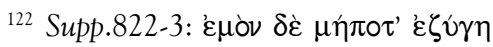

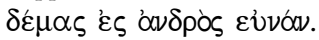


5. Adrasto habla de los capitanes muertos en Tebas. De Partenopeo afirma:

"Y teniendo muchos enamorados, y, mujeres también, otras tantas, se guardaba a fin de no cometer torpeza alguna" ${ }^{123}$.

Leemos en el texto el sustantivo erastēs, usado por el trágico con toda su carga semántica ${ }^{124}$. Según los intérpretes Partenopeo (Parthenopaîos) lleva su nombre, equivalente a "De aspecto virginal", por su madre Atalanta, que se mantuvo ajena al matrimonio durante largos años, hasta que finalmente lo dio a luz (cf. Sófocles, OC 1321-2). Otros indicadores nos señalan que, en la exposición de Adrasto, estamos ante un caso singular, pues se rompe el esquema hasta entonces seguido para hablar de los demás capitanes caídos en Tebas. Debe subrayarse que Partenopeo se mantuvo virgen al haberse abstenido de relaciones sexuales con los dos sexos.

\section{Electra}

1. El labrador, casado con Electra por orden de Egisto, afirma en el prólogo refiriéndose a su esposa:

"A la cual jamás este hombre -séame Cipris testigomancilló en su lecho. Virgen todavía es, pues vergüenza me da, tras tomar hija de padres nobles, violentarla, no siendo digno (...)

Quien afirma que soy necio, si tomando joven virgen para mi hogar, no la toco, con malvadas reglas de su mente midiendo la sensatez, sepa que él mismo es tal”125

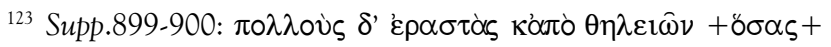

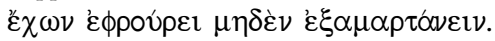

${ }^{124}$ El primero en utilizarlo con evidente sentido sexual es Arquíloco (Fr.374.4). Un uso semejante lo tenemos quizá en Simónides, en el género femenino (5.159.1). En Tr. 1051 aparece, además, la correspondencia léxica del "amado" (erômenos). En Supp. 899 califica a los amantes, masculinos o femeninos, de Partenopeo. En otros pasajes encontramos, en nuestro trágico, una crítica de la pederastia: cf. Cyc.583 ss, Fr. 841.

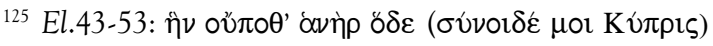

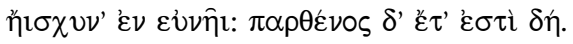

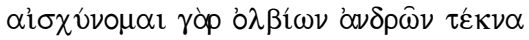


Conviene detenerse, siquiera sea con brevedad, en algunos puntos. Así, el valor moral de aischýnomai, repetido en posición relevante, comienzo de verso: uno, en sentido transitivo, "causarle vergüenza" a otro por sus actos, naturalmente en sentido sexual, de donde "mancillar", "manchar", y otro, con valor intransitivo, "sentir vergüenza uno mismo", también con valor sexual. Nótese cómo se menciona a la diosa de las relaciones sexuales como testigo de sus palabras. La insistencia en la virginidad de Electra es digna de señalar, así como la indicación precisa sobre cómo se comprueba, de modo evidente, ese respeto a la muchacha: eunêi, "en el lecho". Advertimos que, aunque ante la ley, el campesino es esposo de la heroína, en su conciencia no se siente digno (katáxios) de hybrizein, "causarle violencia", también en sentido sexual evidente. El qué dirán es otro factor tenido en cuenta por el humilde trabajador del campo, pues, sin duda, habrá quien le tome por môros, "necio, loco" (término que en Eurípides tiene connotaciones evidentes de matiz sexual, en el sentido de estar loco por un motivo sexual o erótico; además, en este contexto aparece muy cerca de sôphron, que también roza en nuestro poeta la esfera del comportamiento sexual; recordemos, "sensato", sí, pero con valor sexual, es decir, "casto"). Que el personaje está aludiendo claramente a su comportamiento sexual con Electra viene subrayado con el verbo thingánô, "tocar, palpar", es decir, castidad también en lo referente al sentido del tacto.

2. Orestes, en su diálogo con Pílades, resume su situación y propósitos: busca a su hermana, ante todo:

“(...) afirman que, con matrimonio uncida, vive y no permanece virgen" ${ }^{126}$.

Señalemos el verbo zeúgnymi, "poner el yugo", "unir mediante el yugo”, “uncir”, y de ahí, unirse en matrimonio; nótese el dativo instrumental gámois, "en matrimonio", que más bien indica la causa, en la medida en que "matrimonio" no es propiamente un instrumento material. Orestes había oído (phasí) eso de otros, que, seguramente

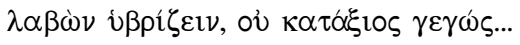

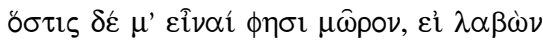

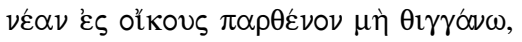

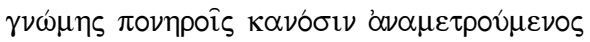

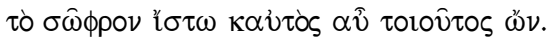

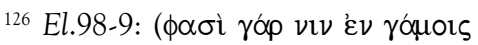

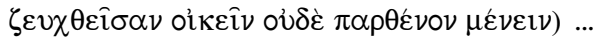


no sabían que Electra seguía manteniendo su virginidad. La situación jurídica y social de Electra, pues, desde todos los ángulos, era la propia de una mujer casada, no la correspondiente a una parthénos. Orestes, posiblemente, con la expresión lingüística oudè parthénon ménein, nos quiere indicar un cierto reproche y desazón, pues, si su hermana ya está casada la situación familiar es diferente; sus planes de venganza (matar a su madre y a Egisto, asesinos de su padre) habrían de ser modificados en algún sentido, y, sobre todo, se iba al traste su intención de casar a Electra con su buen amigo Pílades.

3. La protagonista, en su canto lírico, afirma:

"Mi madre, en lecho sangriento, con otro unida, habita" 127.

Suele entenderse léktrois phoníois como "lecho del crimen" o "sangriento", pero posiblemente cabe ver también una alusión a la unión sangrienta, pues, como sabemos, léktron puede tener asimismo el valor de "unión sexual", dentro del matrimonio legítimo, o al margen de él. Eurípides, verdadero sabio en el manejo del léxico, emplea en esta secuencia el adjetivo sýngamos para calificar a Clitemnestra ${ }^{128}$. La innovación semántica consiste en que Clitemnestra no comparte a nadie con nadie, por lo que, stricto sensu, sobraría el prefijo syn-, ya que, sencillamente, la reina está unida con otro, pero sin simultaneidad ni compañía de nadie, matices indicados, en general, con ese prefijo. Cabe la posibilidad de que el trágico quiera leer entre líneas y pretenda que el espectador inteligente piense en el anterior gámos de Clitemnestra con Agamenón, como si éste continuara con vida (o el recuerdo de aquella unión siguiera vivo y palpitando entre los suyos, a saber, en Orestes y Electra, de modo singular), y, en ese supuesto, sí habría una justificación del sentido del adjetivo, en la medida en que esa unión se da ahora con "otro".

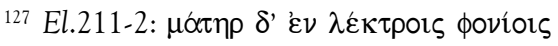

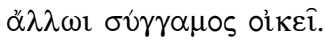

${ }^{128} \mathrm{Si}$ revisamos otros usos del término en nuestro autor, veremos que en HF 149 califica al hombre que comparte con otro la misma esposa (es el caso de Anfitrión), y en Andr.836 se atribuye a una mujer que tiene el mismo marido que otra (se habla allí de Andrómaca y Hermíone). 
4. Orestes, no reconocido todavía por su hermana, dialoga con ella, deseando saber quién y cómo era su esposo:

"Electra. - Un hombre pobre, noble, y, hacia mí, piadoso.

Orestes. - ¿Piedad de qué clase tiene tu esposo?

Electra. - Jamás osó tocar mi lecho.

Orestes. - ¿Manteniendo alguna pureza divina o despreciándote? (...)

Electra. - Injuriar a mis ancestros no lo creyó justo.

Orestes. - iY cómo no gozó tras recibir tal matrimonio?

Electra. - A quien me entregó no lo considera válido, extranjero.

Orestes. - He comprendido; no tenga un día que pagar pena a Orestes.

Electra. - Temiendo eso mismo, y, además, prudente es de nacimiento.

Orestes. - iAy! Noble hombre has mencionado y hay que hacerle bien.

Electra. - Si alguna vez llega a la mansión el ahora ausente.

Orestes. - iLa madre que te tuvo soportó eso?

Electra. - Las esposas son amantes de sus maridos, extranjero, no de sus hijos.

Orestes. - ¿Por qué Egisto te ha hecho ese ultraje?

Electra. - Quería que yo pariera hijos débiles, entregándome a uno tal.

Orestes. - ¿Para que no parieras hijos vengadores?

Electra. - Tales proyectos tuvo. iAsí me pague justicia por ellos!

Orestes. - iSabe que eres virgen el esposo de tu madre?

Electra. - No lo sabe. Con silencio le privamos de eso" ${ }^{22}$.

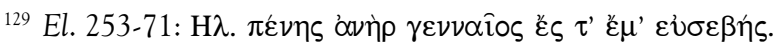

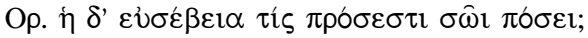

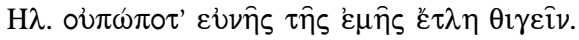

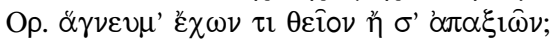

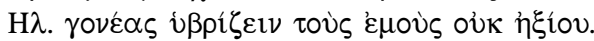

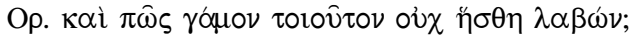

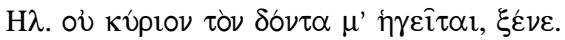

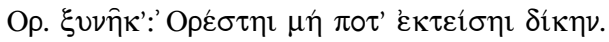

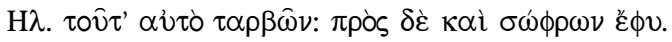

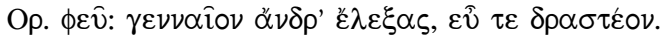


He aquí una secuencia que permitiría un largo excurso aun deteniéndonos sólo un poco en los conceptos esenciales. Digamos, no obstante, alguna cosa. Si Electra afirma que su esposo es gennaîos, está apuntando al comportamiento "noble, humano" del mismo, no a su origen nobiliario. La construcción pénēs anēr gennaîos supone una cierta contradicción aparente, pues un pobre, en la acepción normal del término en la Atenas del momento, raramente puede ser calificado con el adjetivo que designaba a los nobles de nacimiento y estirpe. Pero, en esto, como en tantos aspectos, nuestro trágico es innovador (cf. Or.870), pues se muestra proclive a poner juntos, sin partícula de unión, conceptos aparentemente antinómicos. Por lo demás, ya desde Alceo se observa que hay nobles empobrecidos, y Teognis sostiene que algunos hombres carentes de nobleza pueden adquirirla al haber aumentado su poder económico. Eurípides, pues, recoge en sus obras inquietudes económicas, políticas y sociales de toda actualidad. Pero la clave del trímetro, para nuestro estudio, reside en eusebēs, "piadoso". Por eso, Orestes quiere saber a qué eusébeia ("piedad", "respeto piadoso") se está refiriendo la protagonista, la cual, inmediatamente despeja sus dudas refiriendo al comportamiento sexual tal actitud de piedad y respeto: thigeîn y eunês, nos señalan claramente de qué habla Electra. Entiéndase eunês, en sentido metafórico amplio, como la persona con la que uno se acuesta, es decir, algo más que el puro lugar donde uno duerme. El verbo thingánô lo hemos visto ya en contextos parecidos para expresar la ausencia de trato y contacto sexuales. Sin duda extrañado, su hermano apunta como posibilidad a un hágneum'...theîon, es decir, una pureza, o abstinencia sexual por causa de alguna divinidad o precepto divino ${ }^{130}$. Esencial para comprender estos versos es la noción de "ultraje, violencia, hibris" (cf. El.257: hybrízein, 266: hýbris) que había supuesto

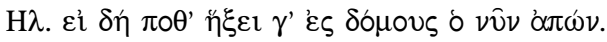

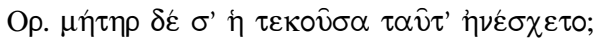

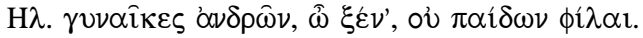

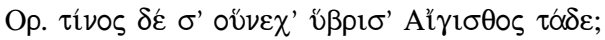

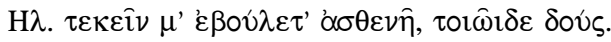

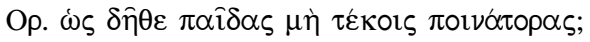

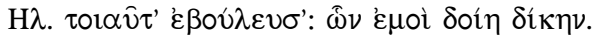

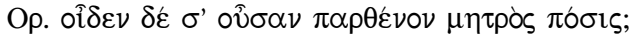

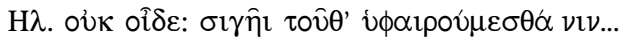

${ }_{130}$ Desde los poemas homéricos contamos con el adjetivo hagnós, "sagrado", que, aparte de calificar a las divinidades o a ciertos elementos importantes como el éter o los ríos, se utilizó para aludir a la pureza y castidad. Sobre ese adjetivo se han formado el verbo hagneúô y el sustantivo hágneuma. En el pasaje euripideo se ha pensado en la posibilidad de que el campesino perteneciera a alguna secta como la de los órficos. Por otra parte, 
la decisión de Egisto al casar a Electra con el campesino; el ultraje no sólo afecta a la muchacha sino también a sus progenitores y ancestros (gonéas); entiéndase, pues, éste adjetivo, aquí sustantivado, con un sentido más amplio que el de "progenitor" (pues, propiamente, lo serían tan sólo Agamenón y Clitemnestra), para pasar a referirse a la familia de los Atridas en general. Otro concepto clave para comprender el pasaje es el adjetivo kýrion (El.259), con el que se apunta a quien tiene plena capacidad, autoridad, legal para llevar a cabo algo: en este caso, dar en matrimonio a una hija. De gran interés son los dos últimos versos seleccionados en los que resulta clara la ignorancia de Egisto respecto a que Electra continúa manteniendo su virginidad, es decir, ella está rompiendo los planes de aquél, según los cuales los hijos de la protagonista serían unos "débiles" (asthenê) para vengar las terribles ofensas que habían sufrido los hijos de Agamenón, cuando éste recibió muerte inicua a manos de su esposa y del amante de la misma.

5. La protagonista le expone su extraña situación a quien cree amigo de su hermano:

"Renuncio a las mujeres por ser virgen, renuncio a Cástor, con quien, antes que llegara junto a los dioses, me prometían, siendo yo un familiar"131.

El texto de Diggle ofrece aischýnomai en v.312 ("me avergüenzo de"), pero los manuscritos ofrecen aquí anaínomai, lectura que, en nuestra opinión, puede mantenerse, pues, además, cuadra con el estilo repetitivo de nuestro autor, proclive a utilizar en idéntico lugar, de dos (o más) versos seguidos, las mismas palabras. La situación de Electra, pues, no es fácil, ya que evita a las mujeres casadas, porque, aunque ella también lo está, sigue siendo virgen. Respecto al verbo mnēsteúô, recordemos, en la Odisea, los mnēstêres ${ }^{132}$, "pretendientes" de Penélope El sentido normal de ese verbo es "buscar una mujer para casarse", pero aquí lo tenemos con el matiz de "desposar", "entregar en matrimonio".

es importante el adjetivo hágios, "sagrado, consagrado", dedicado a la divinidad, vocablo que no aparece ni en Homero ni en Hesíodo ni en los trágicos (Cf. Chantraine, Dictionnaire étymologique, p.25).

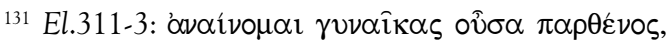

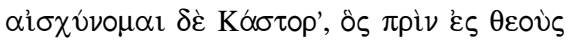

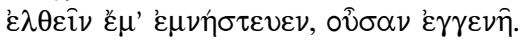

${ }^{132}$ De la misma raíz que mimnêskô, "acordarse de", pero con un matiz especial: "echar de menos", "pretender". 
Sabemos que Cástor, hermano de Clitemnestra, era tío de Electra. No tenemos aquí un rechazo a casarse con alguien de la familia (sí, por ejemplo, en Esquilo) ${ }^{133}$, pues, a diferencia de syngenēs, "familiar directo", engenēs, puede aludir a alguien de lazos familiares más lejanos. En la Atenas del siglo V no era rara, por lo demás, la boda entre tío y sobrina (o tía y sobrino), ni tampoco entre primos hermanos. Por lo que sabemos, esa boda proyectada entre tío y sobrina es una invención de nuestro trágico.

6. En el segundo estásimo, el Coro se refiere al cordero de áureo vellón:

“ (...) palabras

de Tiestes. En lecho oculto

convence a la esposa querida

de Atreo y se lleva el prodigio

hacia su mansión (...)"134.

Encontramos el adjetivo krýphios, es decir, lo que se hace a hurtadillas, de modo oculto, sin que los demás lo sepan. Para "esposa" tenemos el vocablo homérico álochos, propiamente, "la del mismo lecho". Recordemos que Tiestes se acostó con su cuñada, la esposa de su hermano Atreo, y gracias a ella consiguió apoderarse del cordero de piel de oro.

7. Electra increpa al cadáver de Egisto:

"Llegaste a tal punto de ignorancia que esperaste, uniéndote a mi madre, que no sería contra ti malvada, y ultrajabas el lecho de mi padre. iSépalo bien! Cuando uno corrompe a la esposa de otro en lecho oculto y luego se ve forzado a tomarla, desgraciado es si piensa que la que no pudo

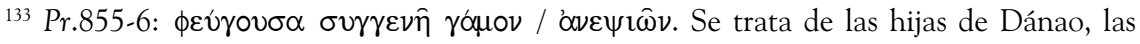
Danaides, que huyen para no casarse con sus primos hermanos, los Egipcios, hijos de Egipto (hermano de Dánao). Las Suplicantes de Esquilo recogen el adjetivo en varias secuencias.

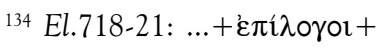

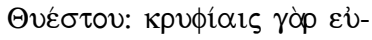

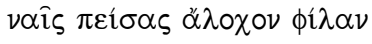
'A $\zeta \varepsilon 1 \pi \rho \circ \varsigma \zeta \omega \mu \alpha \tau \alpha: . .$. 
ser casta allí, junto a él puede serlo.

Vivías con el dolor más terrible, pareciendo que no vivieras de mal modo,

pues sabías, sin duda, que habías contraído unión impura,

y mi madre, que te había adquirido cual varón impío"135.

Varios puntos atraen la atención en esta secuencia. Destaca la consideración general acerca del que corrompe a la esposa (dámarta) de otro en unión oculta, furtiva (kryptaîsin eunaîs; cf. El.719), pues se insinúa aquí un pensamiento que quizá también lo tuvo Egisto: a saber, éste no pretendía casarse con Clitemnestra, pero se vio obligado a tomarla por esposa (anankasthê labein). De otro lado, es fuerte la expresión ándra kektēménē, cuando lo normal es que el varón tome a la esposa, no la mujer al marido. Unos versos más abajo se nos aclara el sentido de lo afirmado: cuando las gentes llamaban a Egisto ho tês gynaikós, "el de su esposa”, contra lo que era de esperar, "la esposa de su marido".

La heroína, además, critica duramente tal situación:

"Además, es vergonzoso esto: que mande en la mansión

la mujer, y no el varón (...)" ${ }^{136}$.

Censura también la belleza de Egisto:

"Que sea mi esposo

no un rostrodoncella, sino de carácter varonil;

los hijos de éstos líganse a Ares,

los hermosos, en cambio, sólo son ornato en los coros"137

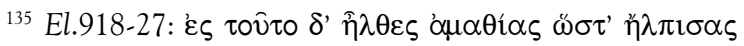

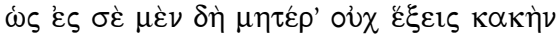

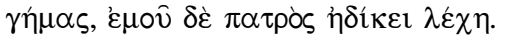

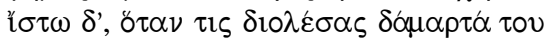

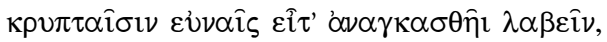

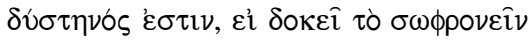

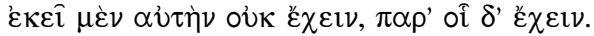

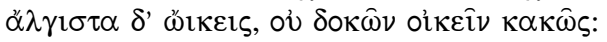

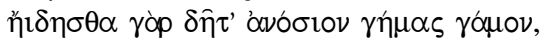

$\mu \eta \eta \tau \eta \delta \dot{\varepsilon} \sigma^{\prime} \alpha^{\prime} \nu \delta \rho \alpha \delta v \sigma \sigma \varepsilon \beta \bar{\eta} \kappa \varepsilon \kappa \tau \eta \mu \varepsilon \dot{\varepsilon} \eta$.

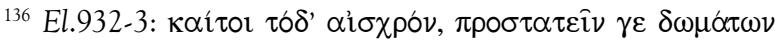

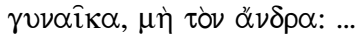


Es una de las ocasiones en que un personaje (aquí, una mujer casada) habla en general, olvidando su condición concreta, como si estuviera libre para contraer matrimonio.

8. Clitemnestra ${ }^{138}$ expone la razón principal por la que diera muerte a su esposo; no fue el sacrificio de Ifigenia, sino otro asunto:

"Vino a mí con enloquecida muchacha poseída por dios, y en el lecho introdújola, y dos esposas en la misma mansión estábamos. Lascivas son las mujeres, no digo otra cosa.

Cuando admitido eso, yerra un esposo rechazando el lecho de dentro, imitar quiere la mujer al marido y adquiere otro amado. Luego, en nosotras brilla la censura, mas los culpables no son criticados duramente por eso" 139 .

La desmesura de Agamenón al presentarse con su amante en el palacio real fue, pues, el detonante de la tragedia familiar. De las palabras de Clitemnestra, podría entenderse que estaba dispuesta a soportar las relaciones sexuales de su esposo fuera del hogar, pero lo que no aguantó de ningún modo es que tuvieran lugar dentro del palacio real ${ }^{140}$.

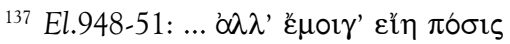

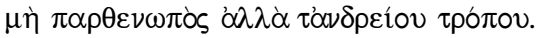

El adjetivo parthenôpós no vuelve a aparecer hasta Dionisio de Halicarnaso (2) y Eliano (1).

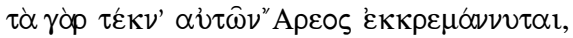

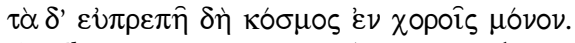

${ }^{138}$ En El. 1027, sostiene que Agamenón dio muerte a Ifigenia porque Helena había sido una márgos, "lasciva", y su esposo (Menelao) no supo castigarla por ello.

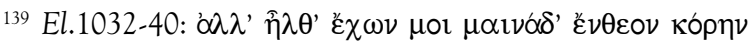

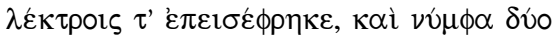

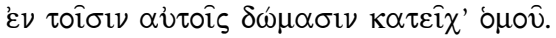

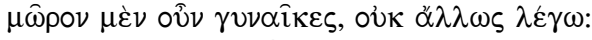

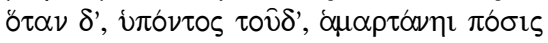

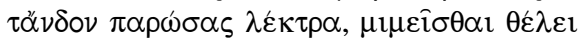

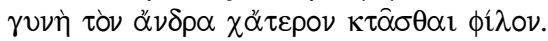

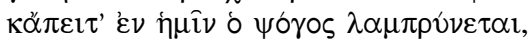

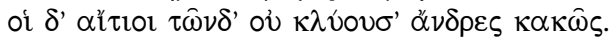

${ }^{140}$ La sofoclea Deyanira tampoco se muestra dispuesta a soportar una situación semejante: Tr.545-6. 
Entiéndase el dual nýmpha, no como "novias", sino esposas; realmente, una sería la esposa, otra la amante. Respecto a môron, "cosa lasciva, algo lascivo", conviene subrayar que en Eurípides tal adjetivo roza la esfera de la sexualidad, indicando la insensatez en el plano sexual. Destaquemos el significado de hamartánēi, "cometer un error, falta", pero en el terreno sexual.

Clitemnestra en esta secuencia se muestra distinta de lo que haría esperar la moralidad griega de los propios años en que la obra es representada: la infidelidad del marido, sobre todo si se encuentra en el extranjero o en campaña militar, es menos censurable que la cometida por la esposa que se ha quedado en el hogar al cuidado de los hijos y del patrimonio familiar. En las Coéforos de Esquilo (Ch.91721) Clitemnestra argumenta que el impulso sexual es irrefrenable y que los excesos de su esposo habían de ser tenidos en cuenta, no menos que los actos que ella pudiera haber cometido; Orestes, en cambio, diferencia claramente allí entre el marido y la mujer, en la línea de lo que acabamos de decir.

9. Electra acusa a su tía y a su madre:

"Una, raptada de grado, se echó a perder (...)

Tú que, antes que se decidiera el sacrificio de tu hija

y recién salido tu esposo de la mansión,

la rubia trenza de tus cabellos arreglabas en el espejo.

Mujer que, ausente su marido, saliendo del hogar

se afana en su belleza, bórrala por ser malvada" ${ }^{141}$.

Otra vez el rapto consentido y deseado por Helena. Hay una cierta contradicción jurídica entre harpázô "raptar" y hekoûs', "por propia voluntad", "aceptándolo", "de grado". En la línea de pensamiento expuesta en los versos anteriores, nos ha llegado un fragmento de nuestro trágico donde se relaciona a Eros con los espejos ${ }^{142}$.

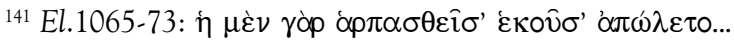

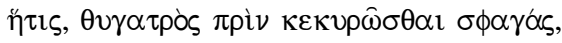

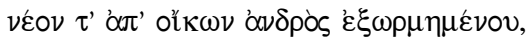

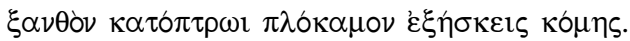

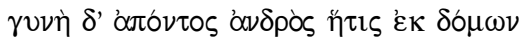

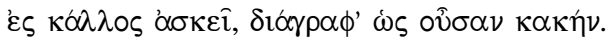

${ }^{142}$ Fr.322.1-2: "Eros es inactivo de natura y en los tales se da. Gusta de espejos y rubias cabelleras (...)" 
Electra, algo más abajo, cuando su madre entra en su humilde morada, afirma:

“(...) te casarás también en la mansión de Hades

con quien dormías a la luz (...)”143.

Advertimos un eufemismo (xyneúdô, "dormir con, junto a") para indicar el adulterio permanente de su madre con Egisto. Recordemos que anteriormente se alude al matrimonio (El.920: gēmas) de los amantes.

Una vez que, junto a su hermano, Electra ha dado muerte a su madre, no sabe a dónde dirigirse:

“iAy, ay de mí! ¿A dónde iré yo?iA qué coro, a qué boda? ¿Qué esposo me recibirá para su lecho nupcial?"144.

El deseo de participar bailando en un coro es muy fuerte, como vemos ${ }^{145}$. Otro acto social de indudable relevancia es la boda (gámon). Electra parece haberse olvidado por completo del campesino, una innovación evidente de nuestro autor. La boda con Pílades, conocida por toda la tradición literaria, se cierne sobre los personajes. La importancia del lecho nupcial (nymphikàs eunás) en el matrimonio queda subrayada en los versos que estamos viendo.

10. Orestes, en su diálogo lírico con el Coro, alude a cómo su madre se quitó el peplo y le mostró el pecho (El.1207: édeixe mastón) en el momento de darle muerte. Era un detalle bien conocido por la tradición literaria ${ }^{146}$.

11. Cástor, deus ex machina, le pide a Orestes que case a Electra con Pílades (El.1284-5); éste regresará a su hogar desde la tierra aquea con doncella y esposa:

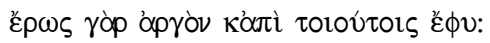

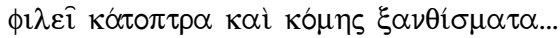

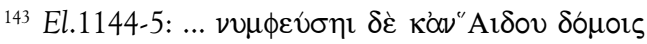

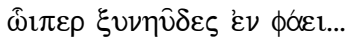

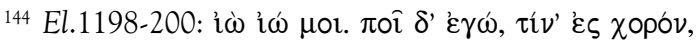

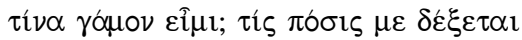

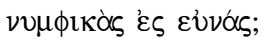

${ }^{145}$ Cf.IT 1143-5, donde Ifigenia echa de menos ese gozo propio de la juventud. ${ }^{146}$ Cf.Esquilo, Ch.896-8. Lo ofrece también nuestro autor: Or. 568.
} 
doncella (kórēn), en cuanto que todavía es virgen, y esposa (dámarta), porque ya está casada.

\section{Troyanas}

1. Posidón, en el prólogo, habla de las esclavas troyanas:

“(...) y con la doncella que

Apolo soberano dejó delirante, con Casandra, omitiendo lo propio del dios y lo piadoso

cásase, por la fuerza, en unión oculta, Agamenón”147.

Varios detalles léxicos nos dan pistas seguras sobre estos versos. Casandra es una virgen (parthénon), y Apolo, el dios a quien estaba consagrada, la hizo dromáda, es decir decir, "errante, delirante". Por otra parte, Agamenón se ha saltado las normas de Febo (tò tô̂ theoû), y, además, la piedad (eusebés), trato respetuoso hacia la divinidad y la humanidad; el rey de hombres se ha unido sexualmente con ella, la hasta entonces doncella que había prometido virginidad perpetua. Se emplea el verbo gaméô, que, en voz activa, se emplea para el varón que toma esposa; sin duda, no es el significado normal el que tenemos aquí, ni para el rey de hombres resultaba apropiado unirse al final de la guerra con una mujer que no podría pasar de la condición de amante o concubina, ya que el ejército aqueo se disponía a regresar a sus respectivos hogares, y aquél tenía legítima esposa. Prueba de que gaméô tiene aquí otro valor es el acusativo skótion ${ }^{148}$ léchos, aposición del complemento directo (Kassándran), a saber, "unión oculta", eufemismo con el que

${ }^{147} \operatorname{Tr} .41-44:$...ฑ๊ $\delta \grave{\varepsilon} \pi \alpha \rho \theta \dot{\varepsilon} v o \nu$

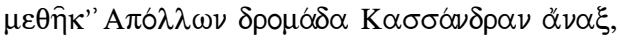

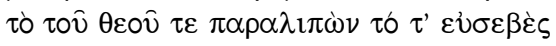

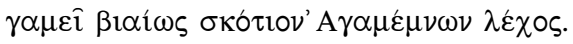

${ }^{148}$ Desde Homero, donde sólo lo aparece una vez, el adjetivo skótios, "oscuro, oculto, secreto", volvemos a encontrarlo en nuestro trágico, el único poeta que lo utiliza en el siglo V, y en bastantes contextos (15). En el cómico Eubulo, Fr. 67.1 leemos:

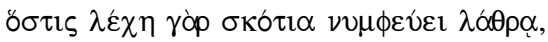

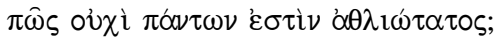

"Quien toma lecho oculto a escondidas, ¿cómo no es el más desgraciado de todos? “ 
se indica que la relación sexual con la virginal doncella sucedería a hurtadillas, al margen de los demás, sin que la gente lo supiera.

2. El Coro de cautivas troyanas, en la párodo, se lamenta:

“(...) sufrimientos mayores tendré,

o uniéndome a lechos de helenos (...)"149.

Entiéndase penalidades todavía peores que la muerte de los varones (padres, esposos, hermanos, hijos) y la pérdida del hogar y la patria; en frase disyuntiva está lo de "acercándome", "uniéndome", eufemismo por la unión sexual con los helenos.

3. En el diálogo epirremático del mensajero Taltibio y Hécuba leemos:

Hécuba. - "¿Quién a mi hija

obtuvo, dime, a la desdichada Casandra?

Taltibio. -Escogida tomóla Agamenón soberano.

Hécuba. -iAcaso, para su esposa lacedemonia, esclava?iAy de mí!

Taltibio. -No, mas novia oculta de su lecho.

Hécuba. - iA la virgen de Febo, a la que cual privilegio

el de áureos cabellos otorgó vida sin lecho conyugal?

Taltibio. -Eros respecto a la doncella poseída por dios lo asaeteó.

Hécuba. -Arroja, hija, muy divinas llaves

y de tu cuerpo los sagrados adornos de bandas envolventes.

Taltibio. -iNo es grande para ella obtener en suerte lecho real?"150

Además, en Plutarco hallamos una referencia a Apolo Escotio (Skótios), "el oscuro" (Mor. 394 a).

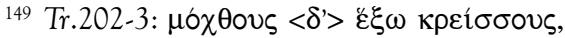

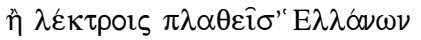

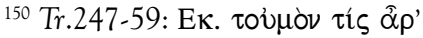

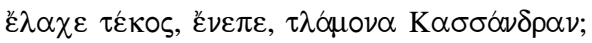

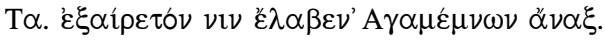

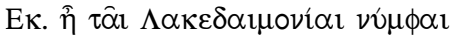

$\delta$ оó่ $\alpha \nu$;

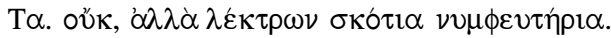

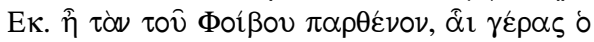

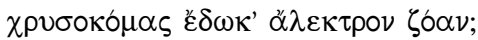

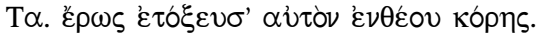


Si Hécuba piensa que el destino de su hija podría ser atender como esclava a Clitemnestra, su estupefacción es total cuando sabe que Agamenón la ha tomado como amante oculta (skótia nympheutêria); advertimos el privilegio concedido por Apolo ${ }^{151}$ a Casandra, que recibe aquí el calificativo de "virgen de Febo", es decir, consagrada a tal divinidad, o lo que es igual, pasar la vida sin estar sujeta al matrimonio (álektron). He aquí un ejemplo evidente de que léktron no significa lecho, sino, por metonimia, lo que normalmente acontece en tal lugar, la unión sexual. Por su parte, la sintaxis nos permite explicar una construcción algo forzada: Eros con genitivo objetivo, es decir, equivalente a un complemento directo: "desear sexualmente a la doncella poseída por el dios" se expresa con el sustantivo correspondiente como "deseo sexual hacia la doncella poseída por el dios", y si mantemos la expresión griega, "Eros de (o "hacia"; o "por") la doncella...". En tal caso, como Hécuba advierte, su hija ha de desprenderse de todo signo externo (unas bandas o cintas indicadoras de su consagración virginal a Febo), muestra de su sacerdocio divino. La réplica de Taltibio no anda escasa de ironía: a Casandra le ha tocado por sorteo (tycheîn) un lecho (entiéndase un amante) real, lo que debería ser importante (méga), dadas las condiciones mucho peores de otras esclavas troyanas.

4. En su canto lírico, Casandra aparece con unas antorchas ${ }^{152}$ :

“(...) iOh soberano Himeneo!

iFeliz el esposo!

iFeliz también yo, que con real esposo

en Argos me uniré!

¡Himen, oh soberano Himeneo! (...)

Yo, para mi boda,

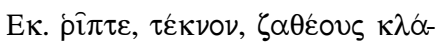

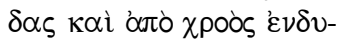

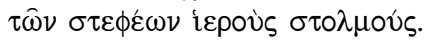

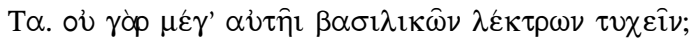

${ }^{151}$ Recordemos que el propio dios de la mesura y el orden había intentado unirse sexualmente con Casandra, y, viéndose rechazado, le concedió el dudoso privilegio de que todas sus profecías fueran verdaderas, aunque nadie las creería ciertas. Cf. Esquilo, A. 1202-1212.

152 Cf. Tr.343-5, donde Hécuba invoca a Hefesto, que porta (daidouchê̂s) la antorcha en las bodas de los mortales. En cambio, Casandra no lleva el fuego (pyrphorêss) de forma adecuada. 
alzo en llamas luz de fuego, para brillo, para resplandor, dándote, ioh Himeneo!, dándote, ioh Hécate!, luz para lechos de vírgenes, según el rito pide.

iHimen, oh Himeneo, Himen! (...)

iGritad a Himeneo, oh, y, con felices cantos y gritos, a la novia!

iEa!iOh las de hermosos peplos, doncellas de los frigios!iCantad al destinado al lecho de mis bodas, a mi esposo" 153 .

Convendría detenerse en varios conceptos esenciales para el objetivo de este trabajo: gamétēs-Himēn-Himénaios-anaphlégôo (insistiendo en el significado de la antorcha y luz nupcial)-Hekátē (la divinidad infernal, porque va a ser una boda que lleve a Hades)-parthénôn léktrois-nómos (en el sentido concreto de estos versos, es decir, la tradición en las ceremonias nupciales)-gámôn-eunâi. La acumulación léxica de términos referentes a la sexualidad, lato sensu, es notoria.

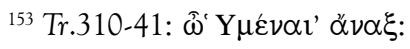

$\mu \alpha \kappa o ́ p l o \zeta ~ o ́ ~ \gamma \alpha \mu \dot{\varepsilon} \tau \alpha \varsigma$,

$\mu \alpha \kappa \alpha p i ́ \alpha$ ' '

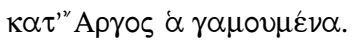

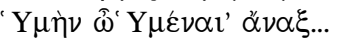

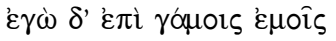
¿ $\alpha \omega \phi \lambda \varepsilon \dot{\varepsilon} \gamma \omega \pi$ upòs $\phi \hat{\omega} s$

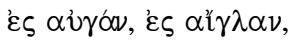

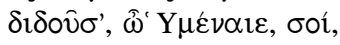

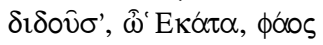

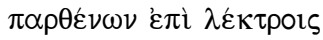

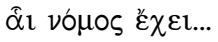

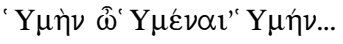

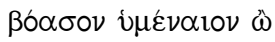

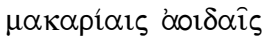

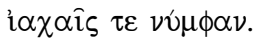
' ' $\tau$ ', $\bar{\omega} \kappa \alpha \lambda \lambda i \pi \varepsilon \pi \lambda$ or $\Phi \rho v \gamma \omega \bar{\omega} \nu$

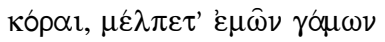

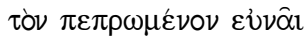
$\pi \delta \sigma u v ' \varepsilon \mu \varepsilon \dot{\varepsilon} \theta \varepsilon v$. 
5. - Casandra, en su delirio, afirma lo siguiente:

“(...) Si Loxias existe,

se casará conmigo, unión más funesta que Helena,

el ilustre Agamenón, de los aqueos señor" ${ }^{154}$.

Véase el acusativo etimológico (gameî...gámon); además, se alude aquí a la unión sexual, pues el rey de hombres no se podía casar con otra mujer sin que se hubiera anulado el matrimonio anterior con Clitemnestra; por otra parte, entiéndase, "unión más funesta que la unión de Helena", o tómese, por metonimia, gámon como "mujer", no "unión".

Y sigue hablando del "señor de hombres":

"el sabio estratego, por lo más odioso, lo más querido perdió, los placeres hogareños

de sus hijos, dándolos a su hermano por mor de una mujer, voluntaria en ello y no raptada por la fuerza"155.

Subrayemos el fuerte sentido irónico de sophós, dicho de un hombre capaz de sacrificar a su hija Ifigenia con tal de seguir con la escuadra hacia Troya; aunque se habla de "placeres", entiéndase referido al singular, pues, si bien durante diez años se vio privado de estar con sus hijos, Agamenón entregó, en bien de su hermano (Menelao), la vida de su hija; el genitivo téknôn puede entenderse como genitivo subjetivo ("placeres que daban sus hijos") o explicativo-epexegético ("placeres: sus hijos”); en la expresión "voluntaria en eso", podemos ver en taût' un acusativo de relación, a saber, en el hecho de haber sido raptada, hablando de Helena; se descarta toda idea de violación o violencia (ou bíai).

6. Taltibio presencia toda la escena, y no puede por menos de lamentar el estado de Casandra:

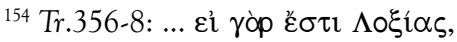

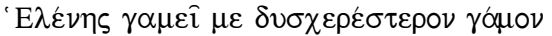

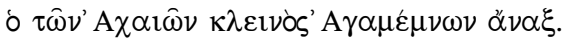

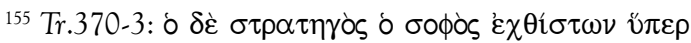

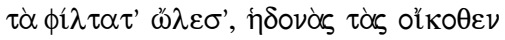

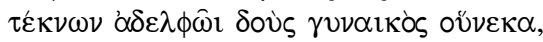

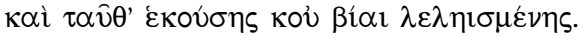


"El máximo señor de los panhelenos, de Atreo querido hijo, el amor elegido de esta ménade apartó. Pobre soy yo, mas el lecho de ésta no pediría"156.

Frente al título tan rimbombante de Agamenón, la simple condición del heraldo, un pobre, como él mismo afirma; si el primero ha seleccionado (hypéstē, "puso aparte") a la ménade como algo exaíreton ("escogido", "elegido" de entre el resto de esclavas), el segundo no la pediría por esposa. Entiéndase léchos como "amante", mujer con la que se comparte el lecho, sin categoría de esposa legítima; además, en el giro "el amor de esta ménade" el genitivo debe explicarse, a nuestro entender, como objetivo: "el amor (deseo erótico) hacia esta ménade".

7. Casandra se arranca las bandas de Apolo:

“iMarchad en jirones lejos de mi cuerpo! iQue, siendo aún pura de [cuerpo, entrego éstas a las rápidas auras para que te las lleven!iOh soberano [profeta!"157.

Nótese el adjetivo hagnē, con un acusativo de relación, chróa, "piel", y, por metonimia, "cuerpo". La idea incluida en hagnē se opone a la condición que tendrá Casandra cuando haya perdido la virginidad. La ménade, como recuerda el pasaje, no ha mantenido todavía relación sexual alguna con su señor.

8. Hécuba alude a la educación que dio a sus hijas:

“(...) y a las doncellas que eduqué

para prestigio selecto de sus novios,

tras educarlas para otros arrebatáronmelas de las manos"158.

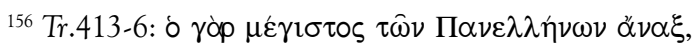

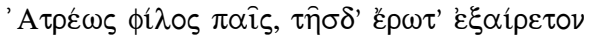

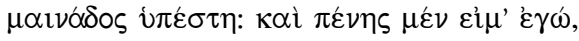

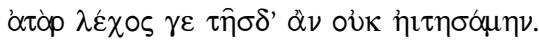

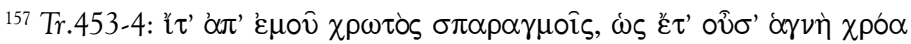

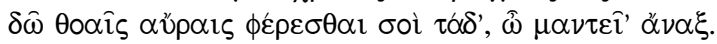

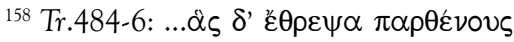

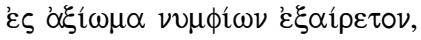

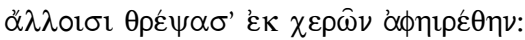


En contextos como éste, según creo, tréphô se desplaza del campo de la nutrición al propio de la educación, la cual, en el fondo, es otro modo de alimentar. La educación recibida serviría a esas jóvenes para dar (o ser ellas mismas) prestigio (axî́ma) a sus prometidos y esposos. Importa señalar la presencia de parthénous y nympiôn (de ambos términos hemos hablado previamente), es decir, que las hijas eran vírgenes antes de haber conocido a sus novios.

Y, con respecto a Casandra, afirma:

“iOh hija!iOh Casandra bacante en compañía de dioses!

iCon qué desgracias has roto tu pureza!"159.

Interesa subrayar de modo adecuado la presencia de hágneuma ${ }^{160}$, es decir, el resultado de ser puro (hágios, hagnós).

9. El Corifeo avisa a la anciana Hécuba de la llegada de Andrómaca:

"Hécuba, ¿ves aquí a Andrómaca

en carro extranjero transportada?

Al compás del remar de sus senos se mueve

el amado Astianacte, retoño de Héctor" ${ }^{161}$.

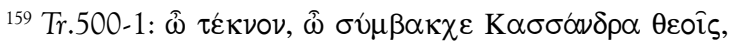

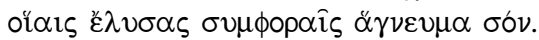

${ }^{160}$ Sólo lo encontramos dos veces en el trágico: aquí y en El.256. Eurípides es el único en utilizar tal sustantivo hasta fines del Va.C. También es la primera y única vez en que aparece sýmbakchos en ese mismo periodo literario.

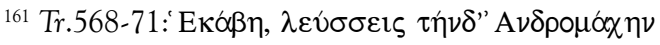

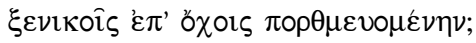

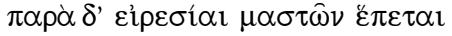

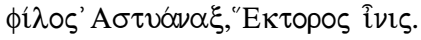

Una imagen distinta, puramente maternal, lejana ya de toda imagen erótica (aun así creo que el movimiento de los senos de Andrómaca contiene cierta dosis de erotismo, si tenemos en cuenta la importancia de los pechos femeninos en nuestro poeta. Seguramente los espectadores de las primeras filas podrían comprobar tal vaivén acompasado de la heró́na que llevaba a su hijito en el regazo), leemos cuando Andrómaca se despide de Astianacte (Tr.758-9):

"En vano, entonces, entre pañales, te nutrió este pecho". 
Recogemos estos versos, no por el contenido sexual, sino por la belleza con que el poeta describe metafóricamente el rítmico movimiento de los pechos de Andrómaca. Es una expresión sin precedentes literarios, constituida sobre un sustantivo "la acción de remar" (eiresía) ${ }^{162}$ no muy utilizado en griego.

10. Andrómaca, en su diálogo con Hécuba, cuenta cómo fue su relación y trato con Héctor y cómo, muerto éste, Neoptólemo quiso tomarla por esposa (Tr.659-60: labeîn/ dámarta):

"Dicen que una sola noche distiende

la aversión de mujer hacia el lecho de varón.

Escupo a la que, rechazando a su esposo anterior, en nueva unión, a otro ama"163.

Interesa subrayar el momento: la noche ${ }^{164}$, propicia para la unión sexual; el rechazo de la mujer al encuentro sexual con el varón (tómese en ese sentido la expresión eis andròs léchos); la acción ritual de repulsa hacia la que comete adulterio (escupir como medida apotropaica); la aparición de kainoîsi léktrois dos versos más abajo, referido, no a "lechos nuevos", sino a "unión sexual nueva"; por último, philê̂, con claro sentido sexual (amar, sí, pero sexualmente. He aquí un claro ejemplo de la extensión y amplitud semántica de la familia léxica de phílos).

La heroína, dirigiendo sus palabras a Héctor muerto tiempo atrás, afirma:

"Tras llevarme pura de la mansión de mi padre, me unciste el primero al lecho virginal" ${ }^{165}$.

${ }^{162}$ Lo tenemos en Od. (3), Píndaro (1), Sófocles (1), Eurípides (6), Dionisio Calco (2); en prosa, lo recogen Heródoto (3), Tucídides (2). Todo ello hasta fines del V a. C.

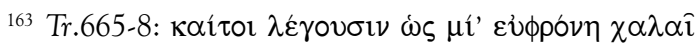

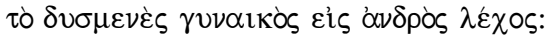

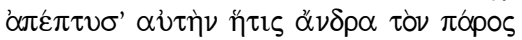

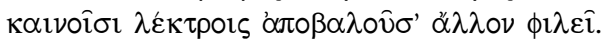

${ }^{164}$ Mencionada mediante el sustantivo euphrónê, propiamente, "la bienintencionada", "la dichosa", "la alegre", aparece en Hesíodo (1:Op.560); luego la registran, entre otros, los tres trágicos: Esquilo (6 veces, al menos), Sófocles (4), Eurípides (12).

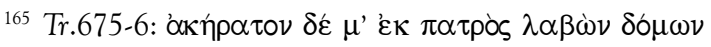

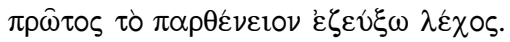


Tenemos ante nosotros el adjetivo akêratos, ya visto anteriormente con sentido sexual; después, la imagen del uncir (ezeúxô, de zeúgnymi), muy ligada al matrimonio, a la pareja, al yugo (zygón) mutuo de los esposos; la expresión tò parthéneion léchos, "hacia el lecho virginal", debe entenderse como el lecho donde una virgen iba a yacer.

11. Menelao expone los motivos por los que fue a Ilio:

"Vine a Troya, no por lo que piensan, por causa de una mujer, sino en pos del varón que, engañador de su huésped, de mi mansión a mi esposa robó"166.

Reparemos en la distribución: gynaikós-ándr'-dámarta. El primer sustantivo tiene el valor de "mujer", en general, opuesto a ándra, "varón"; en cambio, dámarta hace referencia a la esposa legítima. Relevante es la mención de la opinión común, lo que piensan los helenos, los atenienses que están viendo la obra (dokôusi). Conviene subrayar también el verbo elèisato, aoristo de lèÀzo, "robar como pirata", imagen pictórica en desacuerdo con la tradición que sostiene que Helena se fue voluntaria con el troyano.

El héroe advierte que ha ido a llevarse a la "laconia", pues no le gusta mencionar el nombre de la que era su esposa, y ha decidido darle muerte cuando llegue a la Hélade.

12.Hécuba subraya el peligro de mirar a Helena:

"Elógiote, Menelao, si matas a tu esposa.

Mas evita mirar a ésta, no te cautive con deseo.

Atrae las miradas de varones, destruye ciudades, incendia moradas. iTales atractivos posee!" ${ }^{167}$.

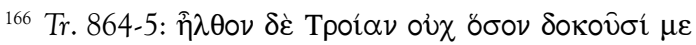

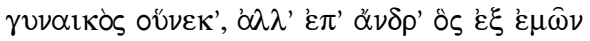

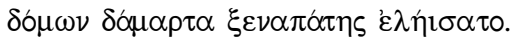

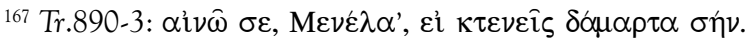

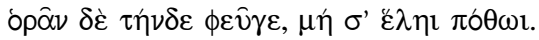

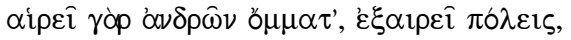

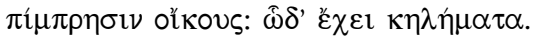

Sólo en Íbico (1) y en este pasaje está registrado el sustantivo kêlêma. 
Varios puntos atraen nuestra atención. El peligro de la vista, por donde los poetas afirman que entra la atracción sexual ${ }^{168}$; la imagen de la cautividad, ser presa del deseo erótico, que es una extensión al terreno amoroso de imágenes procedentes del terreno bélico, heroico: el amor como un ataque y el enamorado como un vencido; que Helena atrae los ojos-miradas de los varones, arrastrados por sus encantos múltiples; los kèlèmata, es decir, conjunto de elementos que sirven para seducir al varón.

13. Helena, en un agón retórico, quiere demostrar que su unión (Tr.932: gámoi, o quizá "bodas") con Paris benefició a la Hélade, aunque a aquél le llama alástôr (es decir, espíritu vengativo, destructor) que llegó acompañado de una diosa no pequeña ${ }^{169}$. Y dirigiéndose a Menelao afirma:

"al cual, ioh cobardísimo!, dejaste en tu mansión

y partiste en nave desde Esparta hacia tierra cretense" ${ }^{170}$.

Añade que, muerto Paris, intentó varias veces escaparse de Troya, pero se apoderó de ella Deífobo (hermano del anterior) y la tenía por esposa (álochon).

14. Hécuba desmonta las razones dadas por la laconia. Entre otros argumentos, ataca el famoso juicio de Paris sobre las tres diosas y acude al ejemplo de Palas:

" $i \mathrm{O}$ es que Atenea buscaba enlace con alguno de los dioses, la que virginidad pidió a su padre, rehuyendo el lecho? (...)"171.

Señalemos la oposición entre gámon y parthéneian: respectivamente, la unión matrimonial y la virginidad. Además, la diosa se lo había pedido a su padre como un don (para los griegos, y de modo especial, los atenienses contemporáneos del poeta, hablar de virginidad, incluso tratándose de una diosa, precisaba cierta

168 Cf.Hipp.525, donde leemos que Eros instila deseo en los ojos.

169 Velada referencia a Afrodita.

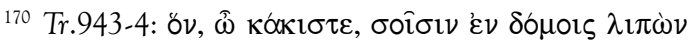

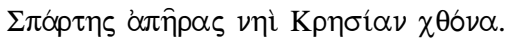

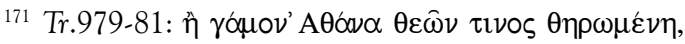

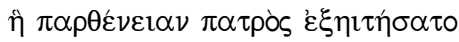
$\phi \varepsilon v ́ \gamma o v \sigma \alpha \lambda \varepsilon \varepsilon \kappa \tau \alpha ; . .$. 
explicación; en el caso de un varón, como vimos en Hipólito, era algo considerado sospechoso y muy raro). La justificación viene en seguida: la diosa rehuía el lecho (pheúgousa léktra), es decir, la unión sexual consiguiente. Precisemos que la diosa Palas pide la virginidad por miedo a la unión sexual (en pheúgô está esa idea de huida, miedo, terror. Cf. phygēe).

Además, sigue diciendo Hécuba, Afrodita no iba con Paris:

"Era mi hijo hermosísimo por su belleza, y tu mente, al verlo, se hizo Cipris.

Las impudicias todas son Afrodita para los mortales, y el nombre de la diosa, con razón, comienza por "insensatez". ${ }^{172}$

Reparemos en môra, "insensateces", adjetivo que en Eurípides es utilizado con frecuencia con una connotación sexual; en el contexto puede rastrearse una etiología del fenómeno amoroso: es la mente humana la que por distintos motivos se transforma en Cipris, es decir, deseo sexual, erótico, y no que la diosa penetre en los mortales (en otros lugares, nuestro poeta tiene otras explicaciones sobre erôs); la explicación etimológica, a la que era especialmente aficionado el trágico, arranca de a-phrosýne, "in-sensatez", como base explicativa de Afrodita ${ }^{173}$

Hécuba utiliza también el argumento de que Helena se vio atraída por el oro de Paris. Por otro lado, nada de rapto, pues nadie oyó sus gritos:

“iBien! Por la fuerza, afirmas que te llevó mi hijo.

¿Qué espartiata se percató?:Qué grito

lanzaste? (...)"174.

Además, cuando Menelao vencía en Troya, Hélena lo elogiaba:

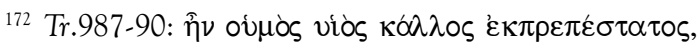

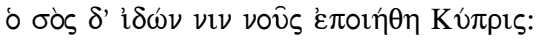

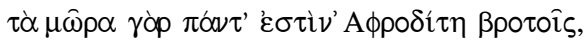

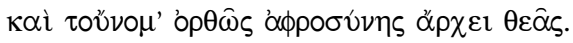

173 Sabemos que el nombre de la diosa debe relacionarse con aphrós, "espuma".

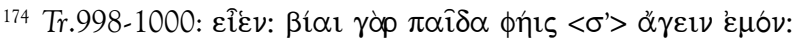

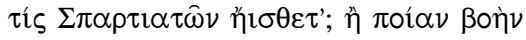
$\alpha \nu \omega \lambda \sigma \lambda v \xi \alpha \varsigma$, 
“(...) para que mi hijo sufriera

al tener gran rival en su pasión”"175.

Nadie vio a la laconia intentando huir; la propia Hécuba le propuso varias veces que se fuera y pusiera fin a la larga guerra, pero Helena se paseaba orgullosa por su palacio y quería que los bárbaros se arrodillaran ante ella. Hécuba, pues, le pide a Menelao que acabe con aquélla:

“(...) establece esta norma para las demás

mujeres: muere la que traicione a su esposo" ${ }^{176}$.

15. El Corifeo interviene para insistirle a Menelao en que le dé muerte a Helena y evite, de parte de la Hélade, el reproche de "afeminado" (thêly) $)^{177}$.

16. Menelao está de acuerdo con Hécuba:

“(...) voluntariamente ésta de mi palacio se fue

hacia un lecho extranjero. Y Cipris, por jactancia, está en sus palabras (...)"178.

17. Hécuba le pide a Menelao que no ponga a Helena en el mismo navío que vaya él. Y he aquí su diálogo con el héroe:

Hécuba. - "No hay amante que no ame siempre.

Menelao. - "Según resulte la intención del amado (...)

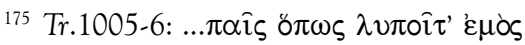

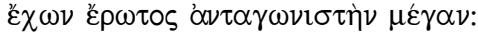

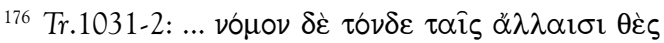

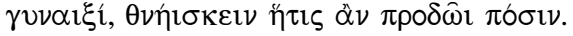

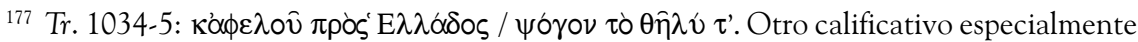
duro, y de índole sexual, que nuestro poeta le aplica a Menelao, personaje que no goza de su simpatía. Epicarmo (1), Heródoto (1) y Eurípides son los primeros en sustantivar el neutro tò $\theta \bar{\eta} \lambda v$ (con tal uso sintáctico lo hallamos 10 veces en el trágico) de un adjetivo ya usado por Homero.

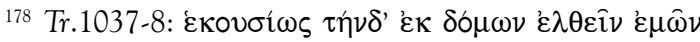

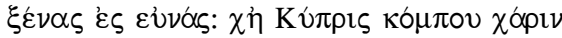
$\lambda$ órols '̇veî $\alpha$ l... 
con todo, la muerte de ésta causará espanto a su impudor, aunque sean incluso peores" ${ }^{\prime 179}$.

\section{INFORME}

Por invitación del Profesor Jaa Torrano, presento este trabajo, elaborado dentro del Proyecto HUM2006-08548 de la Dirección General de Investigación del Ministerio de Educación y Ciencia. El trabajo aparece sin indicaciones bibliográficas, para evitar una extensión excesiva. Aconsejo, al lector interesado, que acuda siempre a las mejores ediciones comentadas del trágico, punto esencial de partida del presente estudio. Me atengo a los datos ofrecidos por el TLG (Thesaurus Linguae Graecae) (32; año 2000), seleccionando los textos más relevantes. La indicación (...) quiere decir que, por brevedad, prescindo de texto innecesario para mi propósito. Las traducciones, versales, son mías, lo más literales y ajustadas posible.

FÉREZ, Juan Antonio López. Sexual allusion in Euripides's tragedies. ABSTRACT: This paper intends to verify explicit or veiled allusion to sexuality in nine works of Euripides.

KEY WORDS: Euripides; tragedy; sexuality.

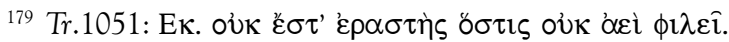

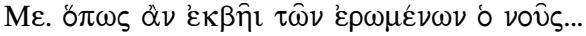

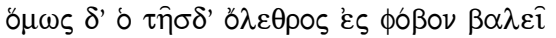

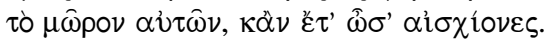

Los dos últimos versos van dirigidos a las mujeres en general. Menelao - el héroe había dicho que los capturadores de Helena se la habían entregado para que él mismo le diera muerte o se la llevara a Argos para acabar allí con su vida (Tr.873-5), mas rechaza, luego, la posibilidad de eliminarla en suelo troyano y decide llevársela a la Hélade para matarla allí (Tr.876-8); además, sostiene ante su esposa que la apedrearán en breve y le harán pagar con la muerte (Tr. 1039-41) y, finalmente, afirma que le quitarán la vida en Argos (Tr.10055-6) - desaparece rápidamente con su consorte de la escena, donde deja a las lamentables troyanas. 